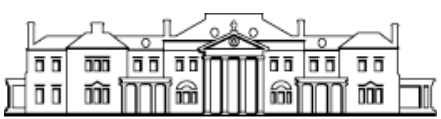

Levy Economics o Institute of Bard College

Working Paper No. 698

\title{
\$29,000,000,000,000: A Detailed Look at the Fed's Bailout by Funding Facility and Recipient
}

by

\author{
James Felkerson \\ University of Missouri-Kansas City
}

December 2011

The Levy Economics Institute Working Paper Collection presents research in progress by Levy Institute scholars and conference participants. The purpose of the series is to disseminate ideas to and elicit comments from academics and professionals.

Levy Economics Institute of Bard College, founded in 1986, is a nonprofit, nonpartisan, independently funded research organization devoted to public service. Through scholarship and economic research it generates viable, effective public policy responses to important economic problems that profoundly affect the quality of life in the United States and abroad.

Levy Economics Institute

$$
\text { P.O. Box } 5000
$$

Annandale-on-Hudson, NY 12504-5000

http://www.levyinstitute.org 


\begin{abstract}
There have been a number of estimates of the total amount of funding provided by the Federal Reserve to bail out the financial system. For example, Bloomberg recently claimed that the cumulative commitment by the Fed (this includes asset purchases plus lending) was $\$ 7.77$ trillion. As part of the Ford Foundation project “A Research and Policy Dialogue Project on Improving Governance of the Government Safety Net in Financial Crisis,” Nicola Matthews and James Felkerson have undertaken an examination of the data on the Fed's bailout of the financial system - the most comprehensive investigation of the raw data to date. This working paper is the first in a series that will report the results of this investigation.

The extraordinary scope and magnitude of the recent financial crisis of 2007-09 required an extraordinary response by the Fed in the fulfillment of its lender-of-last-resort function. The purpose of this paper is to provide a descriptive account of the Fed's response to the recent financial crisis. It begins with a brief summary of the methodology, then outlines the unconventional facilities and programs aimed at stabilizing the existing financial structure. The paper concludes with a summary of the scope and magnitude of the Fed's crisis response. The bottom line: a Federal Reserve bailout commitment in excess of \$29 trillion.
\end{abstract}

Keywords: Global Financial Crisis; Fed Bailout; Lender of Last Resort; Term Auction Facility; Central Bank Liquidity Swaps; Single Tranche Open Market Operation; Term Securities Lending Facility and Term Options Program; Maiden Lane; Primary Dealer Credit Facility; Asset-backed Commercial Paper Money Market Mutual Fund Liquidity Facility; Commercial Paper Funding Facility; Term Asset-backed Securities Loan Facility; Agency Mortgage-backed Security Purchase Program; AIG Revolving Credit Facility; AIG Securities Borrowing Facility

JEL Classifications: E58, E65, G01 


\section{INTRODUCTION}

There have been a number of estimates of the total amount of funding provided by the Federal Reserve to bail out the financial system. While the Fed at first refused to provide data on its bailout, the Congress_-led by Senator Bernie Sanders-ordered the Fed to provide an accounting of its actions. Further, Bloomberg successfully pursued a Freedom of Information Act suit for release of detailed data. That resulted in a "dump” of 25,000 pages of raw data. Bloomberg has recently claimed that the cumulative "spending" by the Fed (this includes asset purchases plus lending) was $\$ 7.77$ trillion. However, the reports have not been sufficiently detailed to determine exactly what was included in that total.

We have conducted the most comprehensive investigation of the raw data to date. We find that the total spending is actually over \$29 trillion. This is the first of a series of working papers in which we will present our results. We hope that other researchers will compare these results with their own, and are providing detailed break-downs to aid in such comparisons.

The extraordinary scope and magnitude of the recent financial crisis of 2007-2009 required an extraordinary response by the Fed in the fulfillment of its lender of last resort function (LOLR). The Fed's response did not disappoint; it was truly extraordinary. The purpose of this paper is to provide a descriptive account of the Fed's response to the recent financial crisis. In an attempt to stabilize financial markets during the worst financial crisis since the Great Crash of 1929, the Fed engaged in loans, guarantees, and outright purchases of financial assets that were not only unprecedented (and of questionable legality), but cumulatively amounted to over twice current U.S. gross domestic product. The purpose of this paper is to delineate the essential characteristics and logistical specifics of the veritable “alphabet soup” of LOLR machinery rolled out to save the world financial system. We begin by making a brief statement regarding the methodology adopted in developing a suitable method with which to measure the scope and magnitude of the Fed's crisis response. The core of the paper will follow, outlining the unconventional facilities and programs aimed at stabilizing (or “saving”) the existing financial structure. Only facilities in which transactions were conducted are considered in the discussion (some facilities were created but never used). The paper will conclude with a summary of the scope and magnitude of the Fed's crisis response. In later working papers we will continue to provide more detailed analysis of the spending. 


\section{METHODOLOGY}

The explicit objective of LOLR operations is to halt the initiation and propagation of financial instability through the provision of liquidity to individual financial institutions or financial markets; or both. At any given moment in time, the available supply of ultimate liquidity is determined by the actions of the Fed and the U.S. Treasury. As the LOLR to solvent financial institutions, the Fed has traditionally found it satisfactory to accomplish its LOLR responsibility through conventional channels. The conventional tools are threefold. When acting as the LOLR, the Fed can increase the availability of liquidity by lending directly to institutions through the discount window; transactions of this nature are conducted at the initiative of participants. It can also make the terms upon which it lends to institutions more generous by decreasing the rate it charges for borrowing or lengthening the repayment period for loans. In recent years, however, preoccupation with control of the money stock has shifted emphasis from measures conducted at the initiative of the borrower to those undertaken at the initiative of the Fed. This new line of thinking holds that the provision of liquidity in times of crisis should be executed through the medium of open market operations. This line of thought argues that the market mechanism will efficiently allocate liquidity to those who have the greatest need during times of heightened demand. And so this third method has come to dominate in Fed actions.

In response to the gathering financial storm, the Fed acted quickly and aggressively through conventional means by slashing the federal funds rate from a high of 5.25 percent in August 2007 to effectively zero by December 2008. The Fed also decreased the spread between its primary lending rate at the discount window and the federal funds rate to 50 basis points on August 17, 2007, as well as extending the term from overnight to up to 30 days. On March 16, 2008, the Fed further reduced the spread to 25 basis points and extended terms up to 90 days. However, the efficacy of the Fed's conventional LOLR tools had little appreciable effect during the initial stages of the recent financial crisis. Moreover, the period of moderation brought about by such measures was of relatively short duration. These actions largely failed to ameliorate rapidly worsening conditions in opaque markets for securitized products such as mortgage backed securities (MBS).

In an attempt to counter the relative ineffectiveness of its conventional LOLR tools, the Fed designed and implemented a host of unconventional measures, unprecedented in terms of size or scope and of questionable legality. The goal of these unconventional measures was to 
explicitly improve financial market conditions and, by improving the intermediation process, to stabilize the U.S. economy as a whole. The authorization of many of these unconventional measures would require the use of what was, until the recent crisis, an ostensibly archaic section of the Federal Reserve Act-Section 13(3), which gave the Fed the authority "under unusual and exigent circumstances” to extend credit to individuals, partnerships, and corporations. ${ }^{1}$

In an attempt to halt growing financial instability, the Fed ballooned its balance sheet from approximately $\$ 900$ billion in September 2008 to over $\$ 2.8$ trillion dollars as of today. Figure 1 depicts the weekly composition of the asset side of the Fed's balance sheet from January 3, 2007 to November 10, 2011. As is clearly indicated in the graph, the Fed's response to events of that fateful autumn of 2008 resulted in an enlargement of its balance sheet from $\$ 905.6$ billion in early September 2008 to \$2,259 billion by the end of the year-an increase of almost 150 percent in just three months! This initial spike in the size of the Fed's balance sheet reflects the coming online of a host of unconventional LOLR programs, and depicts the extent to which the Fed intervened in financial markets. The graph also depicts the winding down of unconventional tools starting in early 2009. However, the decrease was of short duration, as the focus of the Fed shifted from liquidity provisioning to the purchase of long-term securitieswhich, as of November 10, 2011, comprise approximately 85 percent of the Fed's balance sheet.

Figure 2 shows the structure of Fed liabilities over the same period. Casual inspection of the graph indicates the expansion of the Fed's balance sheet was accomplished entirely through the issuance of reserve balances, creating liquidity for financial institutions.

Before moving on to an analysis of the characteristics of each of the facilities implemented by the Fed in its bailout, a methodological note is in order. We have elected to adopt a twofold approach to measuring the scale and magnitude of the Fed's actions during and since the financial crisis. The composition of the Fed's balance sheet is expressed in terms of stocks; that is, it reflects the Fed's asset and liability portfolio at a moment in time. However, the provision of liquidity in the form of reserves by the Fed in the purchase of assets manifests itself as a flow. The outstanding balance of assets and liabilities held by the Fed adjust as transactions are conducted. This is simply a definitional outcome of double-entry accounting. When private sector economic units repay loans or engage in liquidity-absorbing transactions,

\footnotetext{
${ }^{1}$ With the passage of Dodd Frank, the Fed must now make extraordinary crisis measures "broad based." What exactly "broad based" connotes remains to be seen.
} 
the Fed's balance sheet shrinks. Conversely, when private sector agents participate in liquidityincreasing transactions with the Fed, the Fed's balance sheet increases in size.

The changing composition and size of the Fed's balance sheet offers great insight into the scope of the Fed's actions since the crisis. As new, unconventional programs were initiated, they represented a new way for the Fed to intervene in the financial system. Furthermore, given that many of the programs were specifically targeted at classes of financial institutions or markets, and later at specific financial instruments, we are able to identify the markets or individual financial institutions that the Fed deemed worthy of "saving." To account for changes in the composition of the Fed's balance sheet as transactions occur and are settled, we shall report two variables referencing the weekly influence of an unconventional facility on the

Figure 1 Fed Assets, in billions, 1/3/2002-9/28/2011

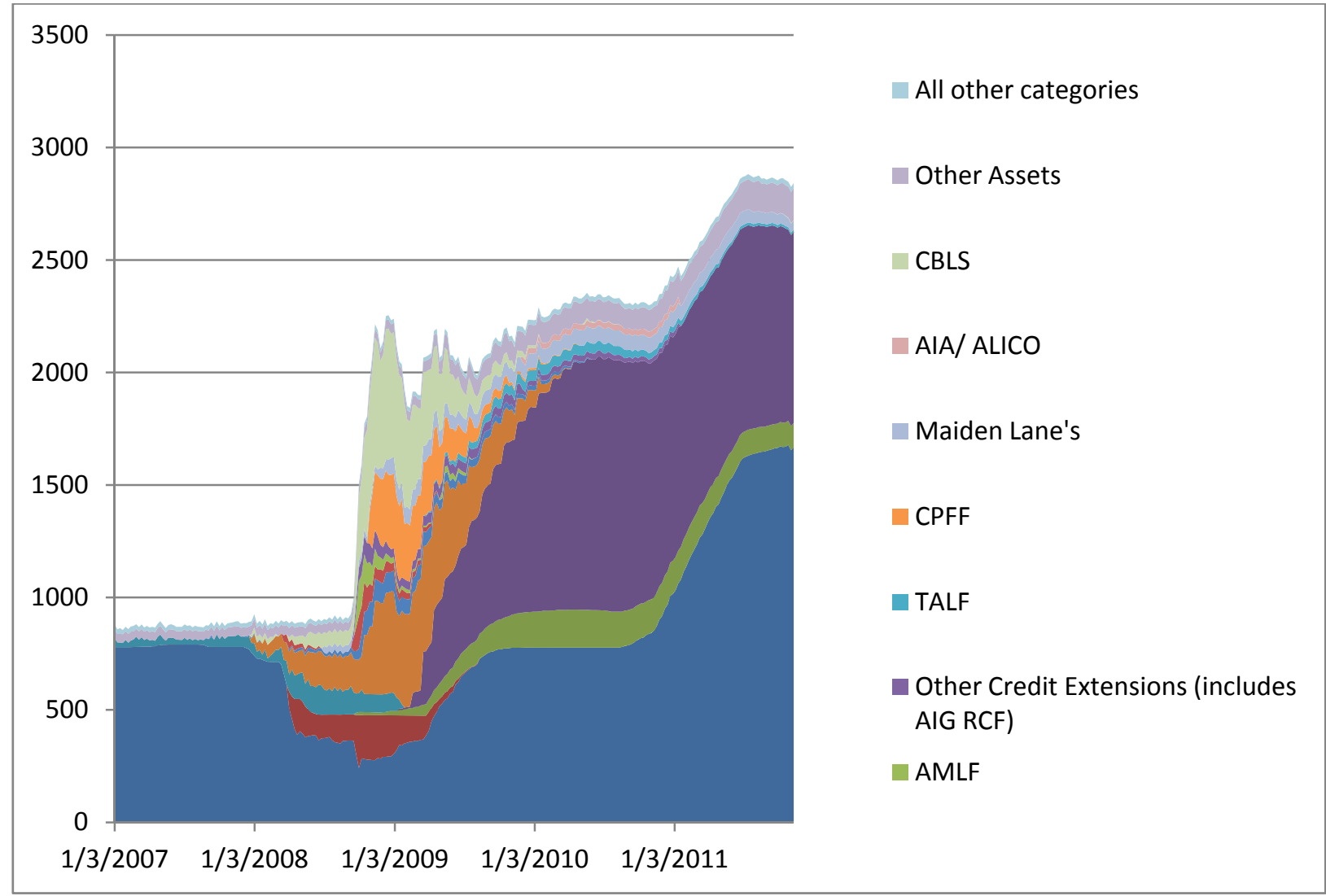

Source: Federal Reserve H.4.1 Weekly Statistical Release and other Fed Sources 
Figure 2 Fed Liabilities, in billions, 1/3/2002-9/28/2008

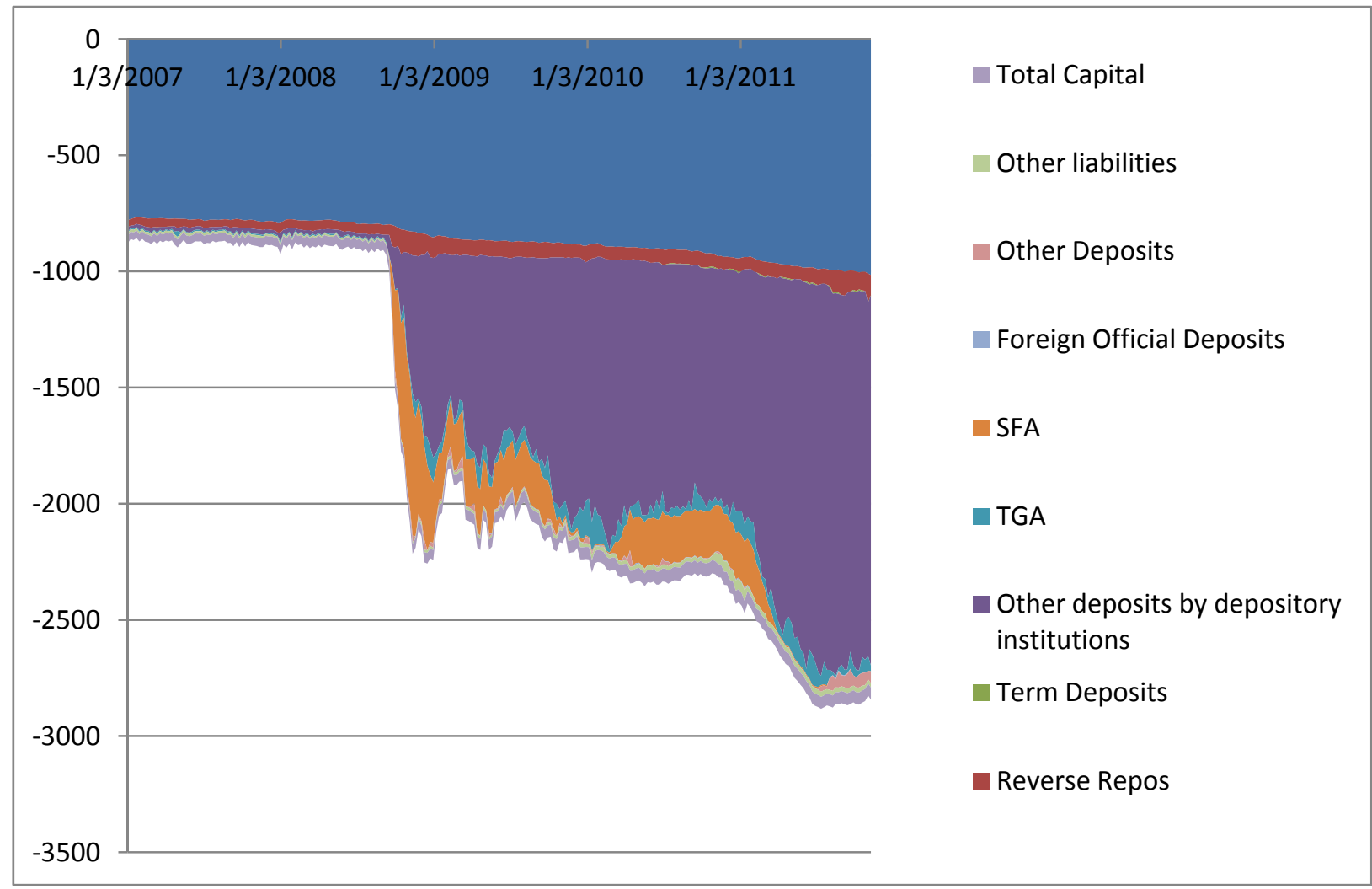

Source: Federal Reserve H.4.1 Weekly Statistical Release and other Fed Sources

composition and size of the asset side of the Fed's balance sheet: the weekly amount outstanding (stock), and the weekly amount lent (flow). The amount outstanding adjusts due to the repayment process, but fails to capture the entire picture. The whole image emerges when we include the weekly amount lent. As will be seen, many of the unconventional actions taken by the Fed were the result of a targeted response to a particularly traumatic event. Given that the respective facilities reflect different terms of repayment, and that initial usage of a crisis facility after an adverse shock was large, the amount outstanding will often increase to a high level and remain there until transactions are unwound. This is captured by the aforementioned "spike" in the Fed's balance sheet. Considering the disparity between lending and repayment, special emphasis will be placed on the peak dates for the amounts lent and outstanding since such time periods were often associated with excessive turmoil in financial markets. However, this leaves us with a dilemma: How are we to measure the magnitude of the Fed's bailout?

Our attempt to capture the magnitude of the Fed's bailout is informed by the idea that when the Fed operates as LOLR, it interrupts the normal functioning of the market process 
(Minsky 1986). To provide an account of the magnitude of the Fed's bailout, we argue that each unconventional transaction by the Fed represents an instance in which private markets were incapable or unwilling to conduct normal intermediation and liquidity provisioning activities. We exclude actions directed at the implementation of monetary policy, or what have been identified as the conventional tools of LOLR operations. Thus, to report the magnitude of the bailout, we have calculated cumulative totals by summing each transaction conducted by the Fed. It is hoped that reference to the changing composition of the Fed's balance sheet and cumulative totals will present both a narrative regarding the scope of the Fed's crisis response as well as inform readers as to the sheer enormity of the Fed's response.

To sum, there are three different measures which we will report; each of which is important in capturing a different aspect of the bailout. First, there is the size of the Fed's balance sheet at a point in time- the total of its assets and liabilities. That tells us how much ultimate liquidity the Fed has provided; it also gives some measure of the risks to the Fed (for example, by looking at its stock of risky assets purchased from banks). Next, there is the flow of lending over a period, as a new facility is created to deal with an immediate need for funds. Spikes will indicate particular problems in the financial sector that required the Fed's intervention. Finally, there is the cumulative total of all the funds supplied by the Fed outside "normal" monetary policy operations, which gives an idea of the scope of the impact of the global financial crisis.

\section{The Facilities (or the Big Bail)}

Several times, the Fed has issued public statements arguing that its crisis response machinery was implemented sequentially and consists of three distinct "Stages." Each "Stage" can be broadly viewed as a response to the evolution of the crisis as it proliferated through financial markets. The characteristics of each facility within the different "Stages" were largely conditioned by a more or less shared set of objectives. ${ }^{2}$ The presentation of the Fed's response as sequential responding to events is useful for the categorization of the unconventional LOLR operations. The rationale for and purpose of the programs initiated during the different "Stages" is indeed chronologically associated with economic events. However, this approach has a major shortcoming in that it does not take into account actions on the part of the Fed directed at

\footnotetext{
${ }^{2}$ See Bernanke 2009 or Sarkar 2009 for an account of this classification scheme.
} 
specific institutions. We have chosen to adopt the "Stages" approach due to its merit as a narrative explaining the Fed's response to major events over the course of the crisis, and included the support provided by the Fed to specific institutions that occurred within the period of time with which a "Stage” is identified. Within each "Stage," we shall present the individual facilities in chronological order.

\section{Stage One: Short-Term Liquidity Provision}

Crisis facilities associated with Stage One were addressed at the provision of short-term liquidity to solvent banks and other depository institutions as well as to other financial institutions (Bernanke 2009). Facilities mobilized under the auspices of Stage One were aimed at "improving aggregate liquidity and also the distribution of liquidity across financial intermediaries” (Sarkar 2009). Sarkar (2009) and Bernanke (2009) identify the objectives of the Stage One facilities as being consistent within the intent of the Fed's traditional LOLR mandate.

The Term Auction Facility (TAF) was announced on December 12, 2007. The TAF was authorized under Section 10B of the FRA and was "designed to address elevated pressures in short-term funding markets” (Federal Reserve 2007). Historically, depository institutions have obtained short-term liquidity during times of market dislocation by borrowing from the discount window or borrowing from other financial institutions. However, the "stigma” associated with borrowing from the discount window led many depository institutions to seek funding in financial markets. ${ }^{3}$ Given pervasive concern regarding liquidity risk and credit risk, institutions resorting to private markets were met with increasing borrowing costs, shortened terms, or credit rationing. To address this situation, the TAF provided liquidity to depository institutions via an auction format. The adoption of an auction format allowed banks to borrow as a group and pledge a wider range of collateral than generally accepted at the discount window, thus removing the resistance to borrowing associated with the "stigma problem.” Each auction was for a fixed amount of funds with the rate determined by the auction process (Federal Reserve 2008a, p. 219). Initially, the auctions offered a total of \$20 billion for 28-day terms. On July 30, 2008, the Fed began to alternate auctions on a biweekly basis between $\$ 75$ billion, 28-day term loans and \$25 billion, 84-day credit. The TAF ran from December 20, 2007 to March 11, 2010.

\footnotetext{
${ }^{3}$ It is believed by many, including the Fed, that discount window borrowing attaches a "stigma" to the borrower. Evidence of its usage is often interpreted as a position of financial weakness, and may result in additional pressures from creditors or inability to find counterparties.
} 
Both foreign and domestic depository institutions participated in the program. A total of 416 unique banks borrowed from this facility. Table 1 presents the five largest borrowers in the TAF. As for aggregate totals, 19 of the 25 largest borrowers were headquartered in foreign countries. The top 25 banks, all of which borrowed in excess of $\$ 47$ billion, comprised 72 percent of total TAF borrowing. Of the 416 unique participants, 92 percent borrowed more than $\$ 10$ billion. Of the $\$ 2,767$ billion borrowed by the largest 25 participants, 69 percent ( $\$ 1,909.3$ billion) was borrowed by foreign institutions. The Fed loaned $\$ 3,818$ billion in total over the

Table 1 Top Five TAF borrowers, in billions

\begin{tabular}{lll} 
Parent Company & $\begin{array}{l}\text { Total TAF } \\
\text { loans }\end{array}$ & Percent of total \\
\hline Bank of America Corporation & $\$ 260$ & $7.3 \%$ \\
$\begin{array}{l}\text { Barclays PLC (United Kingdom) } \\
\text { Royal Bank of Scotland Group PLC } \\
\text { (United Kingdom) }\end{array}$ & 232 & 6.1 \\
$\begin{array}{l}\text { Bank of Scotland PLC (United } \\
\text { Kingdon) }\end{array}$ & 181 & 5.5 \\
Wells Fargo & 154 & 4.7 \\
\end{tabular}

Source: Federal Reserve and GAO

run of this program. As shown in Figure 3, peak monthly borrowing occurred in January 2009 at \$347 billion; while the peak amount outstanding was, in early March 2009, at approximately \$493 billion. The last auction held for this facility occurred on March 8, 2010 with loans maturing on April, 8 2010. All loans are said to have been repaid in full, with interest, in agreement with the terms of the facility. 
Figure 3 TAF, weekly amounts outstanding and lent, in billions

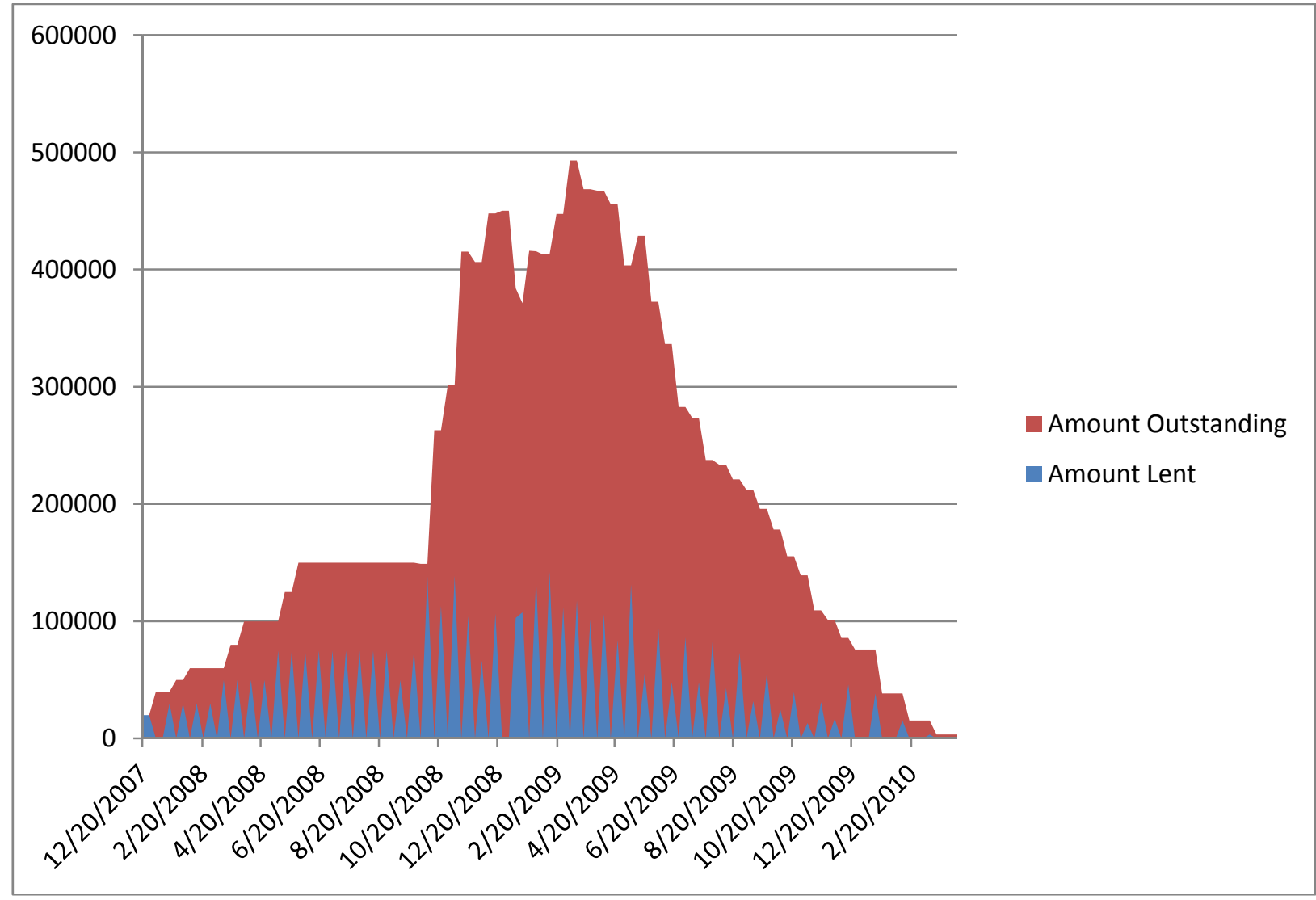

Source: Federal Reserve

As an additional response to "pressures in short-term funding markets,” the Fed opened up currency swap lines with foreign central banks called the Central Bank Liquidity Swap Lines (CBLS) (Federal Reserve 2007). With the CBLS, two types of credit arrangements were created under the authorization of Section 14 of the FRA. Dollar liquidity swaps were arrangements that allowed foreign central banks to borrow dollars against a prearranged line of credit. The CBLS are structured as a repo contract in which the borrowing central bank would sell to the Fed a specified amount of its currency at the exchange rate prevailing in foreign exchange markets. Simultaneously, the participating foreign central bank would agree to buy back its currency on a specified date at the same exchange rate at a market-based rate of interest. The first swap lines were set up in December 2007 with the European Central Bank (ECB) and the Swiss National Bank (SNB). Over the course of the crisis, the Federal Open Market Committee (FOMC) would also open up liquidity swap lines with numerous other foreign central banks. The facility ran 
from December 2007 to February 2010 and issued a total of 569 loans. ${ }^{4}$ Figure 4 presents the percentage of total borrowing by foreign bank counterparties. Table 2 presents total borrowing by each foreign central bank. Peak monthly lending occurred in October 2008 at $\$ 2.887$ trillion. Figure 5 shows the peak outstanding, reaching its high in December 2008 at $\$ 583.13$ billion and peak weekly lending occurring in mid October 2008 at $\$ 851.286$ billion. In total, the Fed

Table 2 CBLS borrowing by foreign central bank, in billions

\begin{tabular}{lrlr}
\multicolumn{1}{c}{ Borrower } & \multicolumn{1}{c}{ Total } & \multicolumn{1}{c}{ Borrower } & \multicolumn{1}{c}{ Total } \\
\hline European Central Bank & $\$ 8,011.37$ & Sveriges Riksbank (Sweden) & $\$ 67.2$ \\
Bank of England & 918.83 & Reserve Bank of Australia & 53.175 \\
Swiss National Bank & 465.812 & Bank of Korea (South Korea) & 41.4 \\
Bank of Japan & 387.467 & Norges Bank (Norway) & 29.7 \\
Danmarks Nationalbank & 72.788 & Bank de Mexico & 9.663 \\
(Denmark) & & &
\end{tabular}

Source: Federal Reserve

lent $\$ 10,057.4$ billion to foreign central banks over the course of this program as of September 28, 2011. Thus far, all transactions were repaid in full, in accordance with the terms of the swap agreements.

\footnotetext{
${ }^{4}$ It should be noted that on June 29, 2011, the Fed extension of the swap lines through August 1, 2012 (Federal Reserve 2011a). As November 10, 2011, \$1.96 billion remains outstanding.
} 
Figure 4 Foreign central bank borrowing by percentage

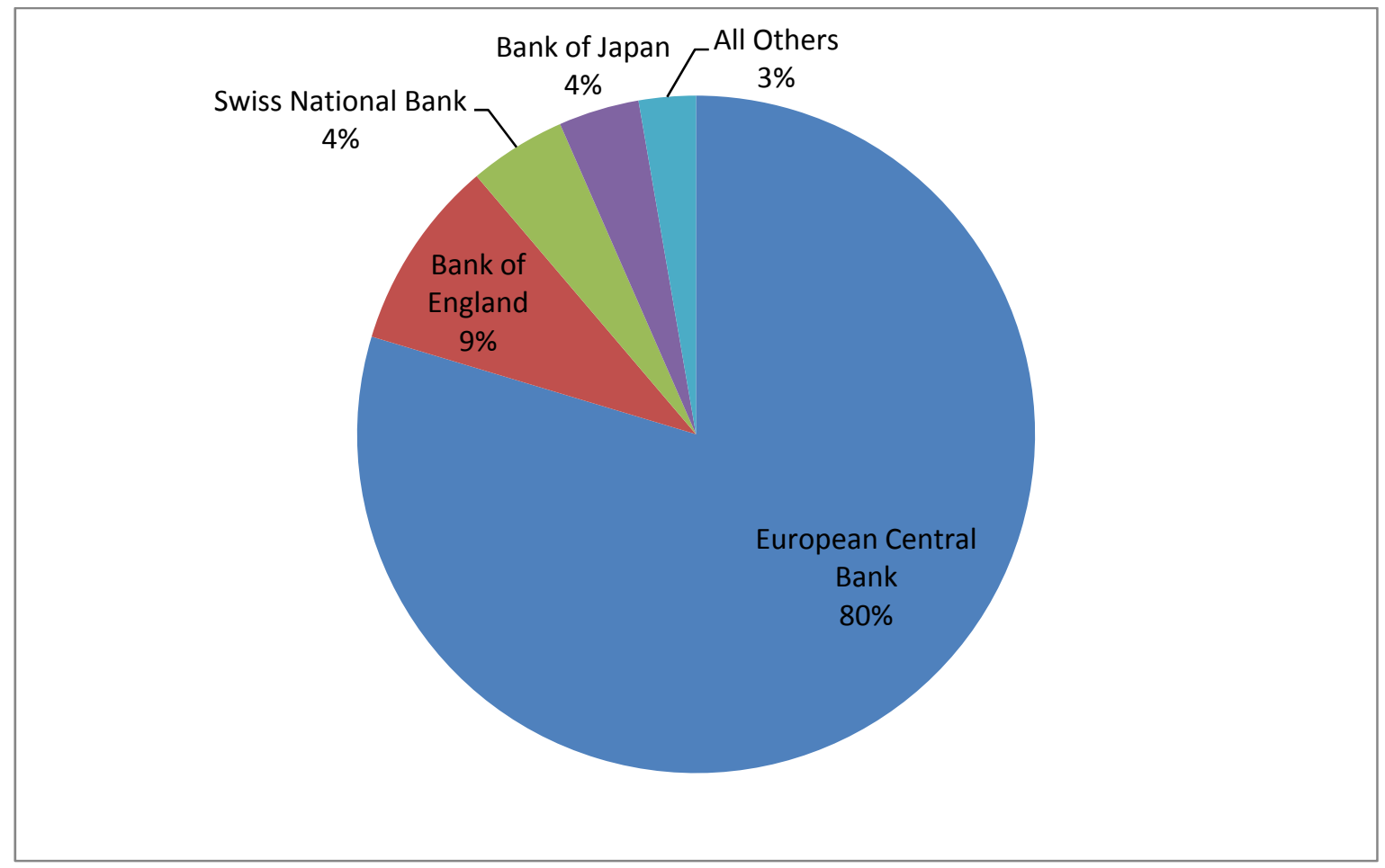

Source: Federal Reserve

As it became apparent that existing conventional and nonconventional LOLR operations were failing to adequately allocate liquidity, the Fed announced on March 7, 2008 that it would conduct a series of term repurchase transactions (ST OMO) expected to total \$100 billion. These transactions were 28-day repo contracts in which primary dealers posted collateral eligible under conventional open market operations. The Fed is authorized to engage in open market transactions by Section 14 of the FRA, and such operations are to be considered a routine part of the Fed's operating toolkit. However, we have chosen to include these transactions as part of the Fed's unconventional LOLR response, since their explicit purpose was to provide direct liquidity support to primary dealers. In 375 transactions, the Fed lent a total of $\$ 855$ billion dollars. Peak monthly transactions occurred in the months of July, September, and December 2008 at $\$ 100$ billion, consistent with the level of lending the Fed had expected. As these transactions were conducted on a schedule, the amount outstanding quickly peaked on April 30, 2008 at $\$ 80$ billion and remained at that level until the facility was discontinued on December 30, 2008. All extant primary dealers participated. Of these 19 institutions, nine were headquartered in foreign countries. 
Figure 5 CBLS weekly amounts lent and outstanding, in billions

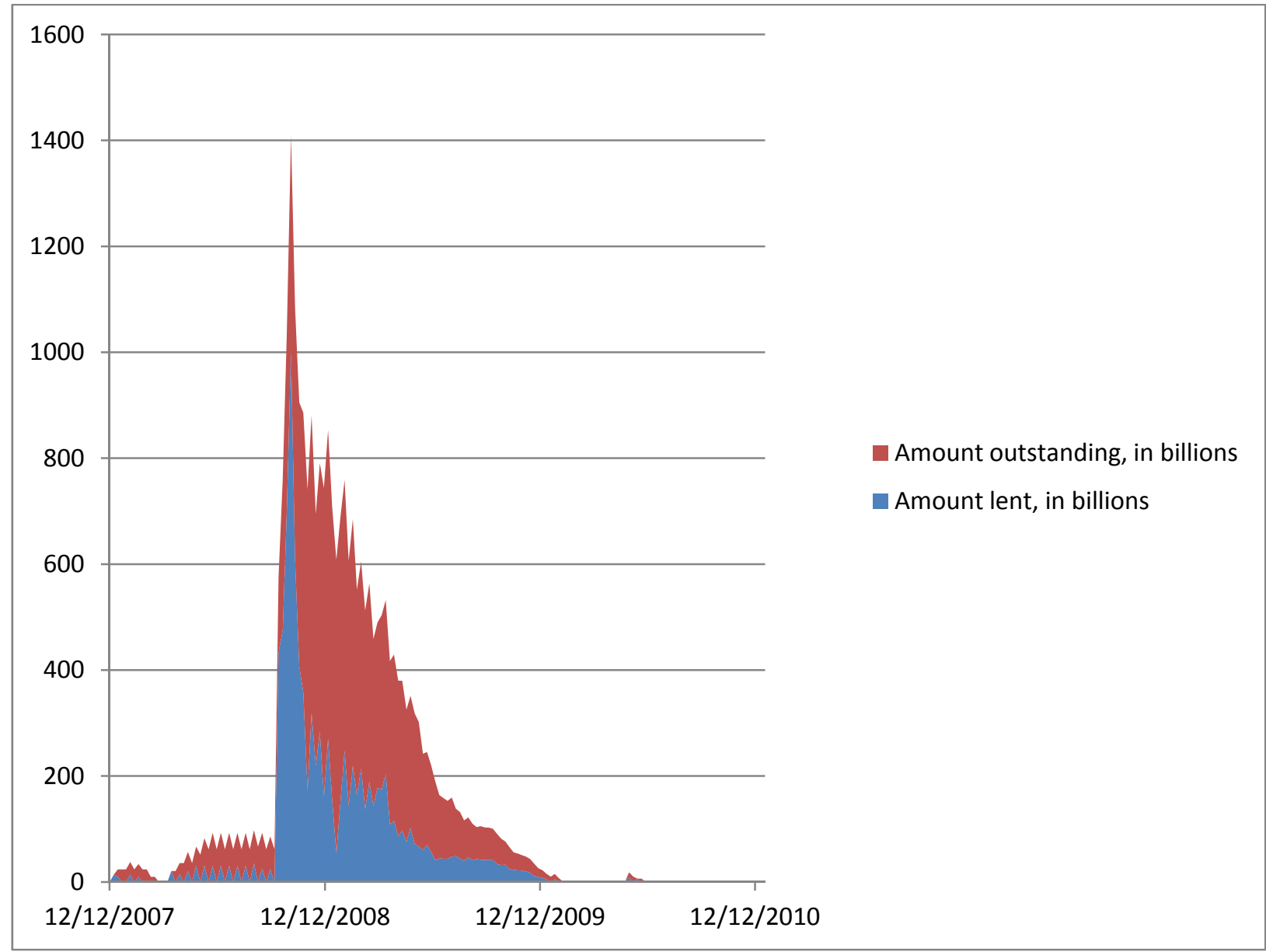

Source: Federal Reserve

Table 3 presents the five largest program participants; all of which were foreign institutions. Transactions conducted with the five largest participants would comprise 65 percent of the program total. As indicated in Figure 6, 77 percent ( $\$ 657.91$ billion) of all transactions were conducted with foreign-based institutions.

Table 3 Largest five ST OMO participants, in billions

\begin{tabular}{lll} 
Participant & Total & $\begin{array}{l}\text { Percent of } \\
\text { total }\end{array}$ \\
\hline Credit Suisse (Switzerland) & $\$ 259.31$ & $30.3 \%$ \\
Deutsche Bank (Germany) & 101.03 & 11.8 \\
BNP Paribas & 96.5 & 11.3 \\
RBS Securities (United Kingdom) & 70.45 & 8.2 \\
Barclays Capital (United Kingdom) & 65.55 & 7.8
\end{tabular}

Source: Federal Reserve 
To supplement the aid provided to investment banks through the ST OMO and address widening spreads in repo markets that were having an adverse impact on the allocation of liquidity, the Fed announced on March 11, 2008 that it would extend its Treasury lending program to "promote liquidity in the financing markets for Treasury and other collateral and thus to foster the functioning of financial markets more generally” (Federal Reserve 2008a). This nonconventional expansion of a conventional program was named the Term Securities Lending Facility (TSLF) and began conducting auctions on March 27, 2008. ${ }^{5}$ The Fed instituted a two-fold classification scheme for eligible collateral under the TSLF. Schedule 1 collateral was identified as "federal agency debt, federal agency residential-mortgage-backed securities (MBS), and non-agency AAA/Aaa-rated private-label residential MBS” (Federal Reserve 2008a). Schedule 2 included agency collateralized-mortgage obligations and AAA/Aaa-rate commercial-mortgage-backed securities, in addition to Schedule 1 collateral. In addition to the TSLF, the Fed announced the TSLF Options Program (TOP), to facilitate access to liquidity in funding markets during periods of elevated stress, such as quarter-ends, on July 30, 2008. The

Figure 6 Single Tranche Open Market Operations percentage by country

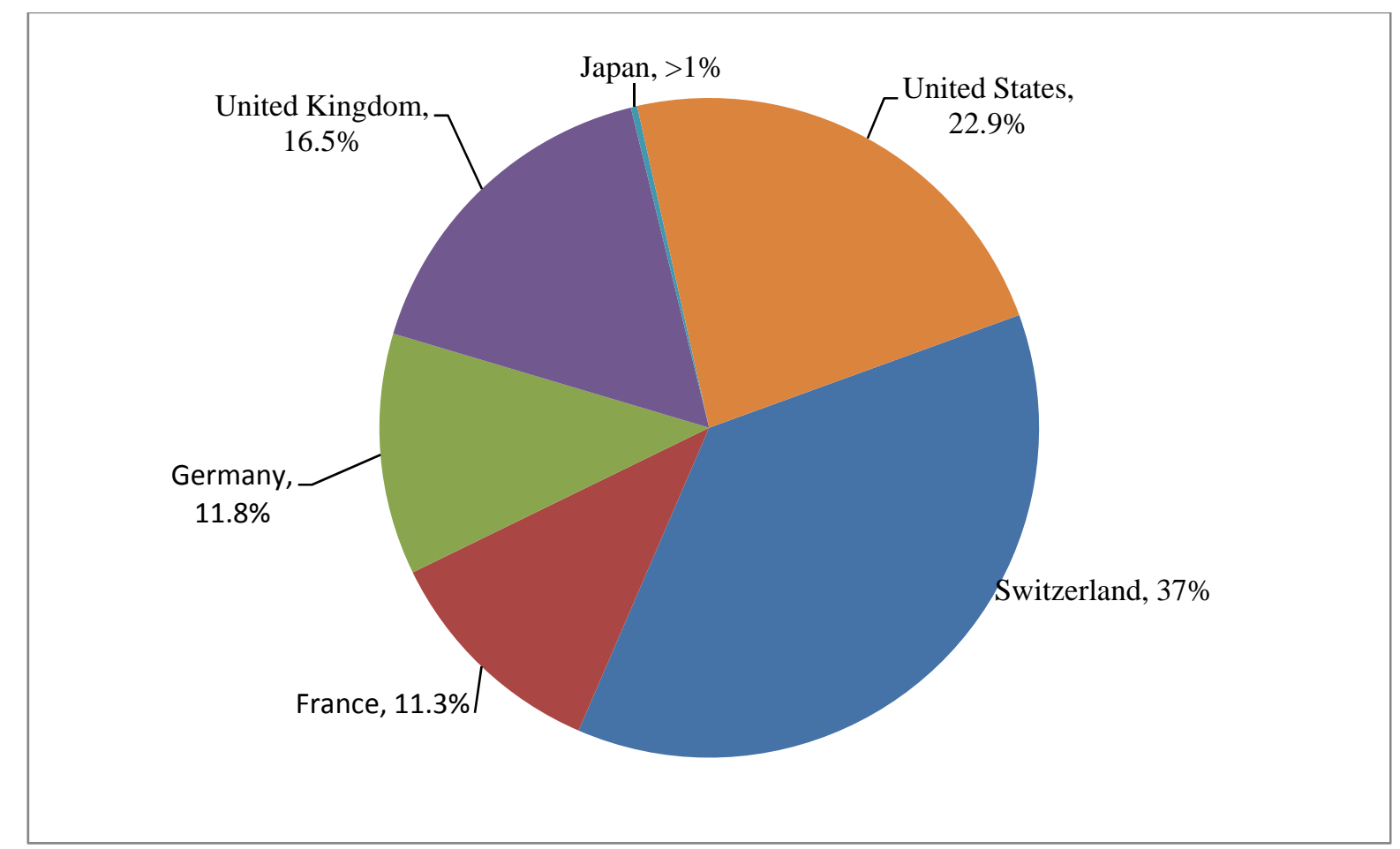

Source: Federal Reserve

\footnotetext{
${ }^{5}$ It needs to be noted that the Fed routinely engages in overnight lending of Treasury securities. Following the Fed's lead, we include transaction undertaken as part of the TSLF as part of the Fed's crisis response.
} 
TOP allowed participants to purchase the right but not the obligation to borrow funds if it became necessary. The TSLF and TOP facilities are important as they mark the first use by the Fed of the powers given under Section 13(3) of the FRA.

Eighteen primary dealers participated in the TSLF program, while only 11 accessed the TOP facility. Of the 18 participants that took part in the TSLF, TOP, or both, eight were foreign institutions. Table 8 presents the five largest TSLF participants, while Figure 7 shows that 51 percent of total borrowing was undertaken by foreign-based institutions. Figure 8 indicates that 86 percent of total borrowing was done by the nine largest program participants. Figure 9 shows

Table 8 Five largest TSLF and TOP participants, in billions

\begin{tabular}{|c|c|c|c|}
\hline Borrower & Totals & Borrower & Total \\
\hline Citigroup Global Markets & $\$ 348$ & Credit Suisse (Switzerland) & $\$ 261$ \\
\hline $\begin{array}{l}\text { RBS Securities Inc. (United } \\
\text { Kingdom) }\end{array}$ & 291 & Goldman, Sachs \& Co. & 225 \\
\hline $\begin{array}{l}\text { Deutsche Bank Securities } \\
\text { (Germany) }\end{array}$ & 277 & & \\
\hline
\end{tabular}

that the week ending September 10, 2008 was the largest in terms of lending ( $\$ 110.848$ billion) and the week ending October 1 the peak for amount outstanding ( $\$ 235.544$ billion). The Fed lent $\$ 1,940$ billion through the TSLF and another $\$ 62.3$ billion under TOP for a cumulative total of \$2.0057 trillion. All loans are said to have been repaid on time in full, with interest, within the terms of the program. 
Figure 7 TSLF/ TOP borrowing by country

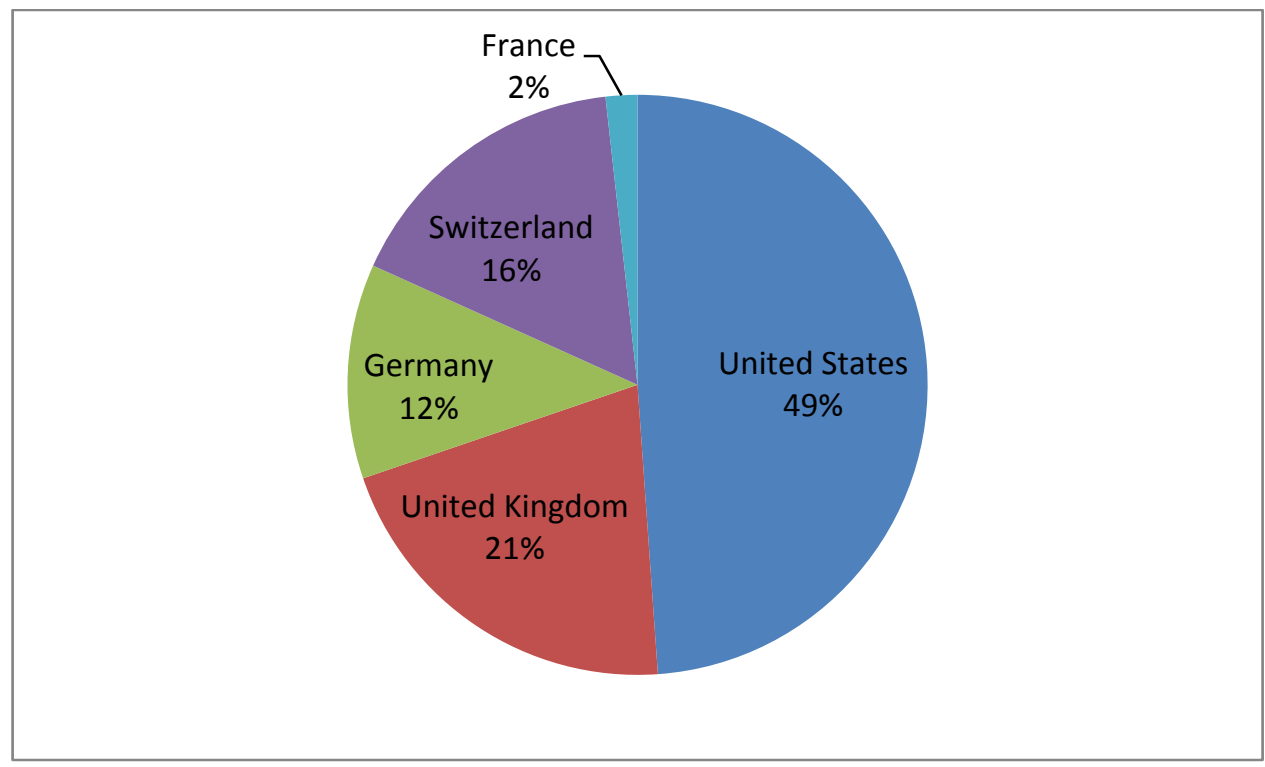

Source: GAO

Figure 8 TSLF percentage by participants

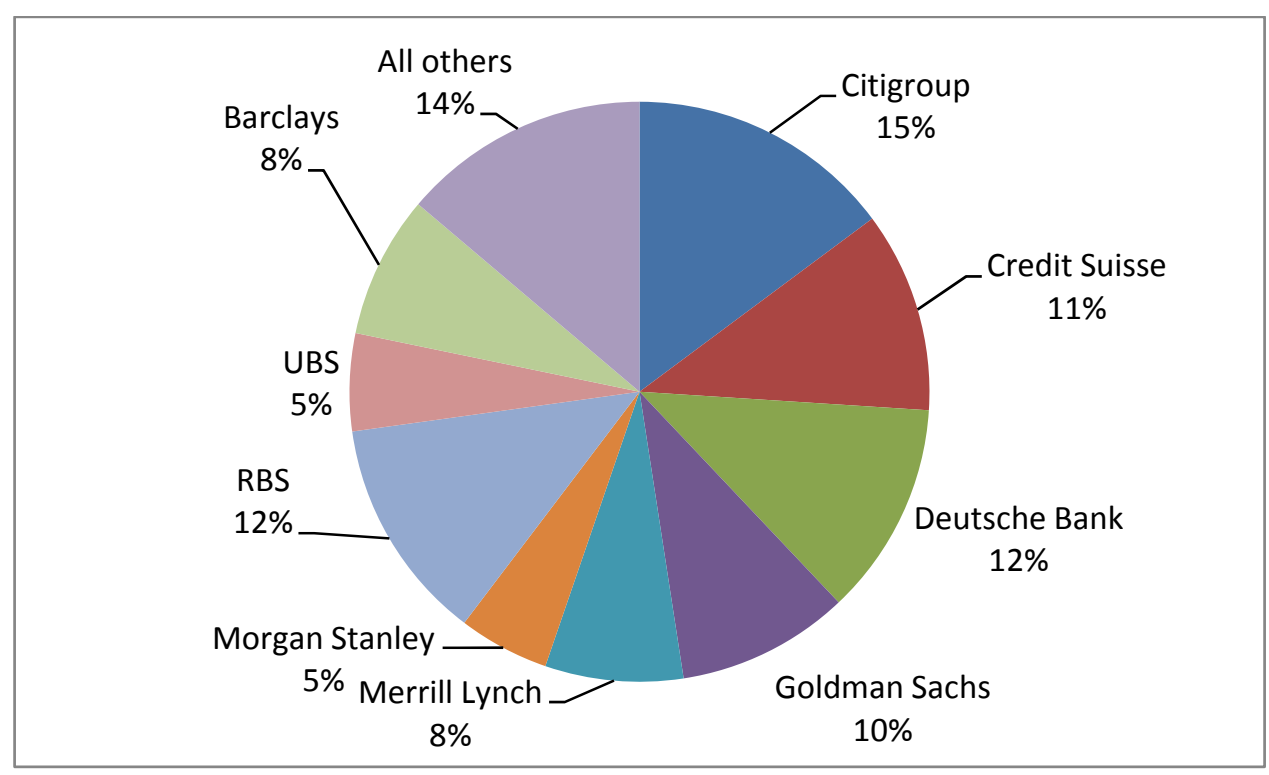

Source: GAO

It is also during Stage One that the first instance of the Fed offering assistance to a specific institution appears. Throughout early-to-mid March 2008, Bear Stearns was experiencing severe liquidity funding problems as counterparties refused to enter into transactions with it, even for assets of unquestionable quality. Problems in securing access to liquidity resulted in Bear informing the Fed on March 13 that it would most likely have to file 
for bankruptcy the following day should it not receive an emergency loan. In an attempt to find an alternative to the outright failure of Bear, negotiations began between representatives from

Figure 9 TSLF, weekly amounts lent and outstanding, in billions

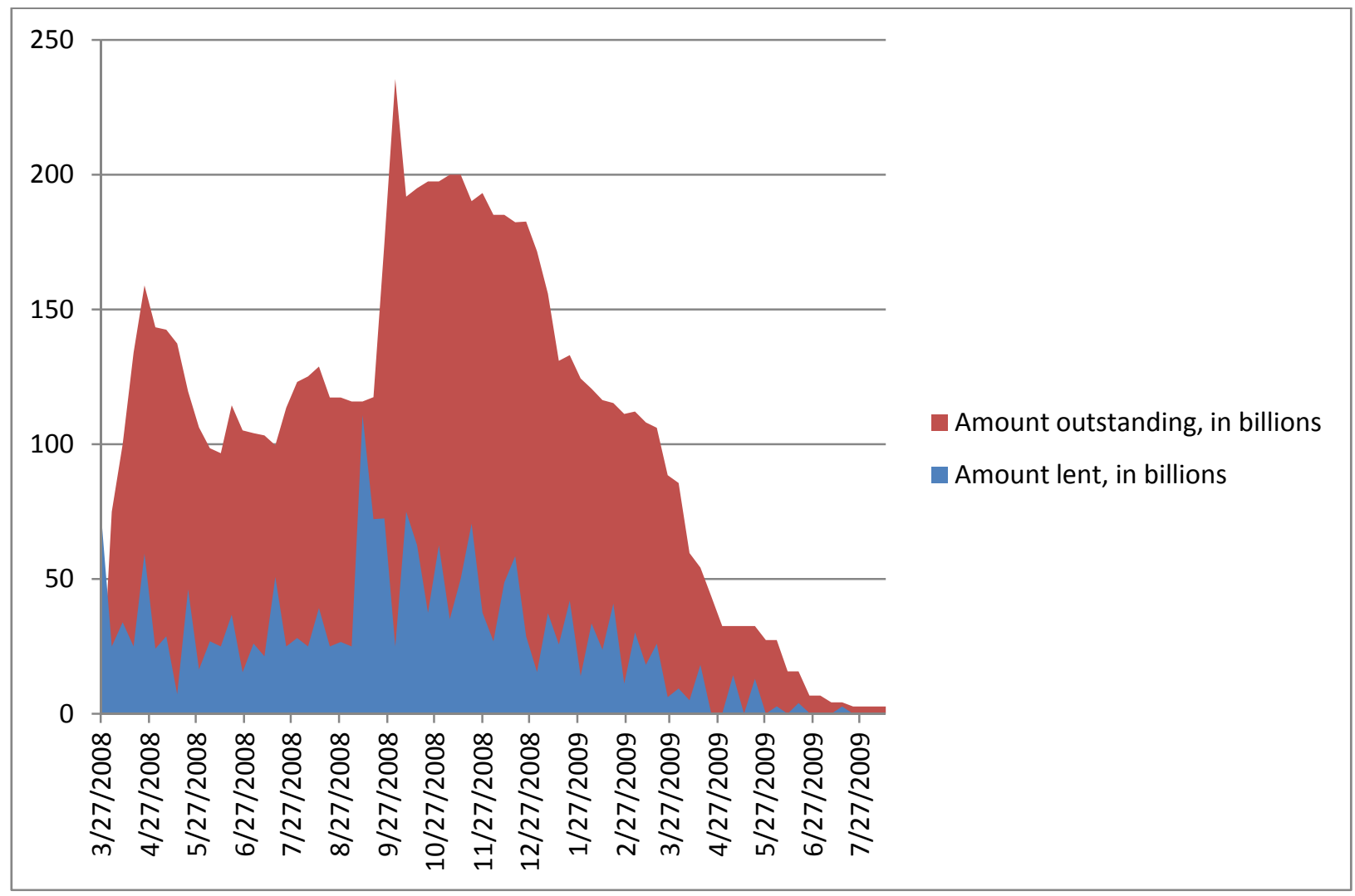

Source: Federal Reserve

the Fed, Bear Stearns, and J.P. Morgan. The outcome of these negotiations was announced on March 14, 2008 when the Fed Board of Governors voted to authorize the Federal Reserve Bank of New York (FRBNY) to provide a $\$ 12.9$ billion loan to Bear Stearns through J.P. Morgan Chase against collateral consisting of $\$ 13.8$ billion. This bridge loan was repaid on Monday, March 17 with approximately $\$ 4$ million in interest. This temporary measure allowed Bear to continue to operate while courting potential buyers. On March 16, J.P. Morgan agreed to a provisional merger with Bear Stearns. Subsequent negotiations formulated the structure of J.P. Morgan's acquisition of Bear Stearns. The purchase of Bear was accomplished when the FRBNY ( $\$ 28.82$ billion) and J.P. Morgan (\$1.15 billion) funded a special purpose vehicle (SPV), Maiden Lane, LLC (ML I), which purchased Bear's assets for the approximate market value of $\$ 30$ billion. Authorization to conduct the transaction was provided by Section 13(3) of the FRA. Maiden Lane, LLC would repay its creditors, first the Fed and then J.P. Morgan, the 
principal owed plus interest over ten years at the primary credit rate beginning in September 2010. The structure of the bridge loan and ML I represent one-time extensions of credit. As onetime extensions of credit, the peak amount outstanding occurred at issuance of the loans.

As the Fed endeavored to prevent the disorderly failure of Bear Stearns over the weekend of March $15^{\text {th }}$, it was also laying the groundwork for implementing a standing credit facility to assist primary dealers. The Fed officially announced the Primary Dealer Credit Facility (PDCF) on March 16, 2008 in an attempt to prevent the effects of the Bear Stearns situation from disrupting markets. The PDCF would function essentially as a "discount window for primary dealers" and provide a nonmarket source of liquidity that would ease strains in the repo market (Adrian, Burke, and MacAndrews 2009). Authorized by Section 13(3) of the Federal Reserve Act, the PDCF would lend reserves on an overnight basis to primary dealers at their initiative. PDCF credit was secured by eligible collateral, with haircuts applied to provide the Fed with a degree of protection from risk. Initial collateral accepted in transactions under the PDCF were investment grade securities. Following the events in September of that year, eligible collateral was extended to include all forms of securities normally used in private sector repo transactions. In addition, the Fed approved loans to the United Kingdom-based subsidiaries of Goldman Sachs, Morgan Stanley, Merrill Lynch, and Citigroup. The PDCF issued 1,376 loans totaling $\$ 8,950.99$ billion. Shown in Figure 10 below are the peak weekly amounts outstanding and lent, occurring on September 26, 2008 at $\$ 146.57$ billion and $\$ 728.643$ billion respectively. ${ }^{6}$ Table 9 lists the five largest borrowers from the PDCF. Figure 11 captures the heavy usage of

\footnotetext{
${ }^{6}$ Since the PDCF issued overnight loans, Figure 10 should be read carefully. The amount outstanding reflects only loans for one day, while the amount lent includes the total of loans for a week.
} 
Figure 10 PDCF, weekly amounts lent and outstanding, in billions

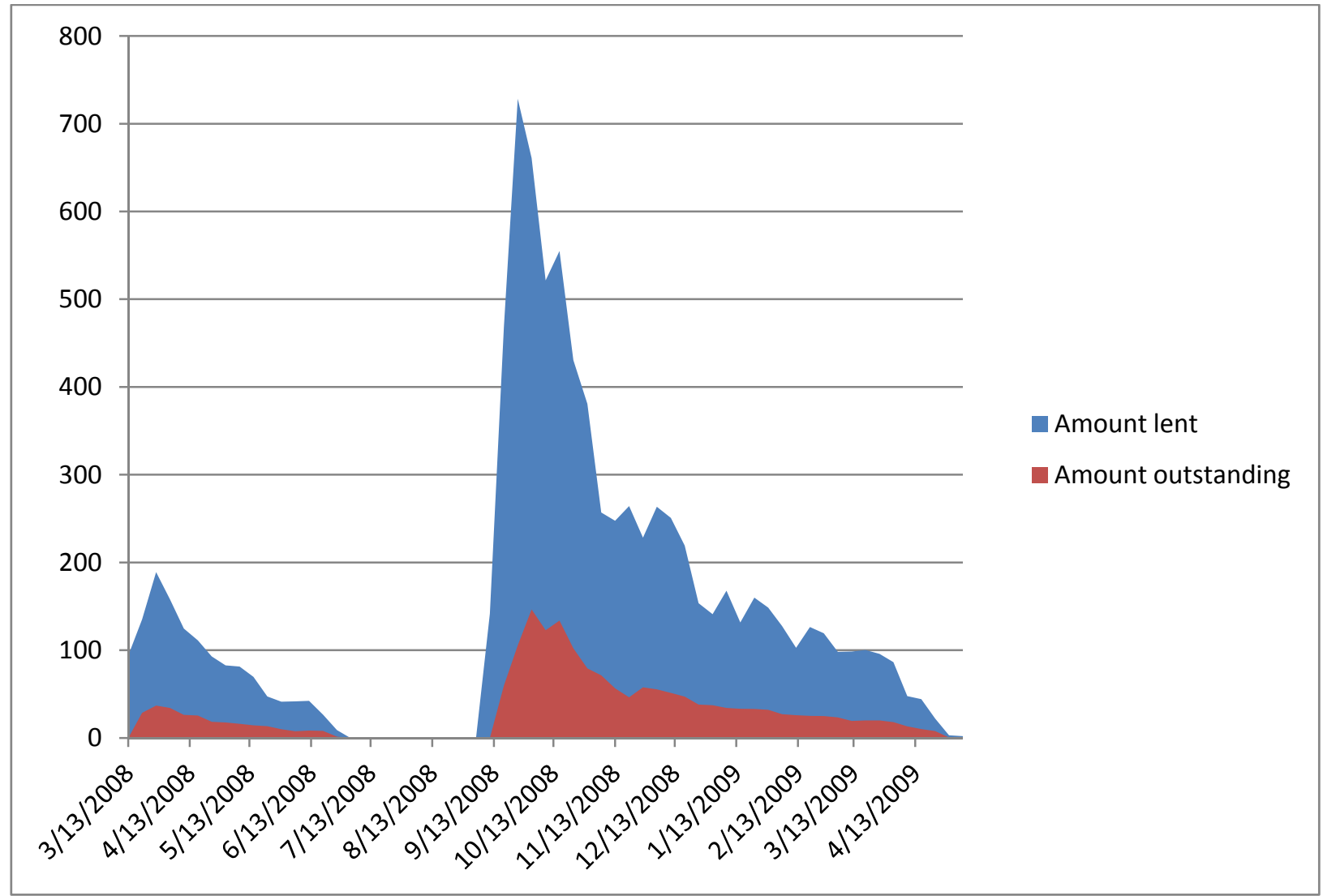

Source: Federal Reserve

the PDCF by the largest borrowers. As the graph shows, the five largest borrowers account for 85 percent (\$7,610 billion) of the total. Eight foreign primary dealers would participate in the PDCF, borrowing just six percent of the total. The PDCF was closed on February 1, 2010. All loans extended in this facility have been repaid in full, with interest, in agreement with the terms of the facility.

Table 9 Five Largest PDCF borrowers, in billions

\begin{tabular}{ll} 
Borrower & Total \\
\hline Merrill Lynch & $\$ 2,081.4$ \\
Citigroup & $2,020, .2$ \\
Morgan Stanley & $1,912.6$ \\
Bear Stearns & 960.1 \\
Bank of America & 638.9
\end{tabular}

Source: Federal Reserve 
Figure 11 PDCF, borrowing by institution

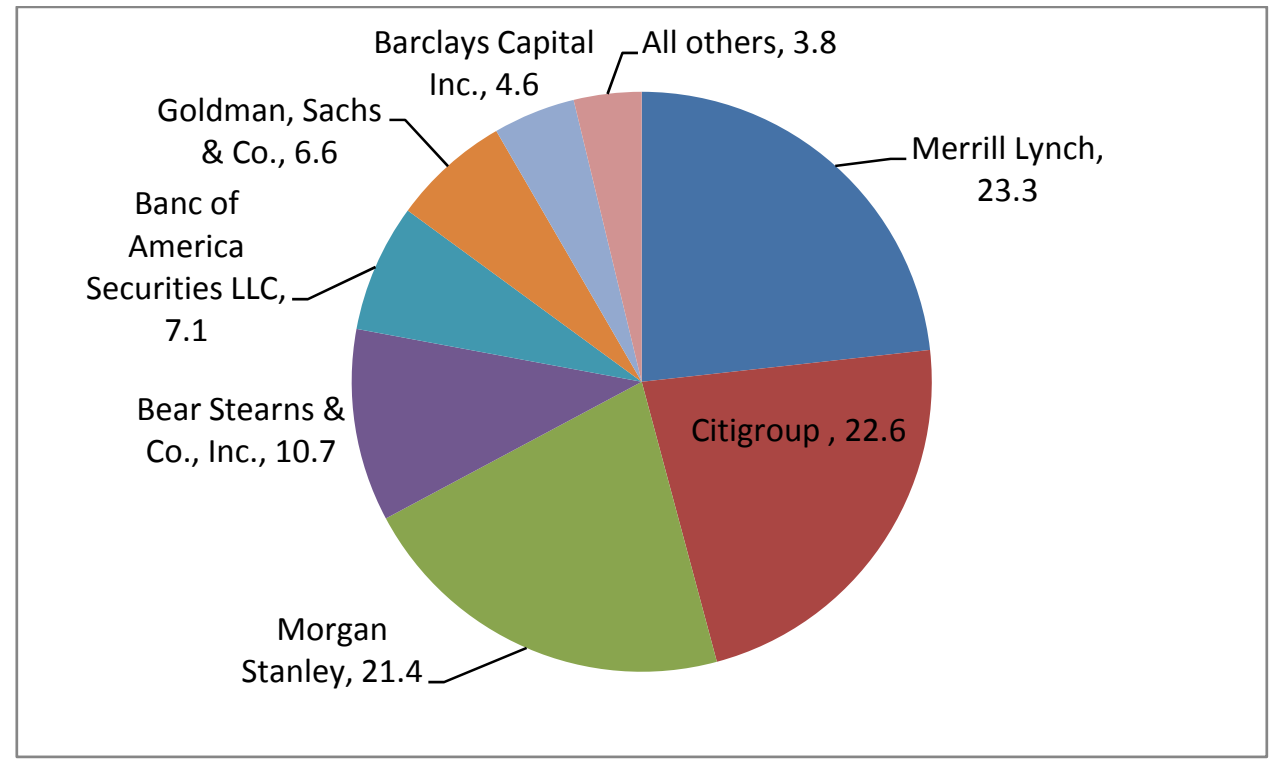

Source: Federal Reserve

In its involvement with American Insurance Group (AIG), the Fed again acted as LOLR to a specific institution. Confronted by the possibility of the voidance of millions of personal and business insurance products, the Fed took steps to ensure AIG's survival through several targeted measures. To provide AIG with space to create a viable plan for restructuring, the Fed provided AIG with a revolving credit facility (RCF) on September 16, 2008, which carried an \$85 billion credit line; the RCF lent \$140.316 billion to AIG in total. To assist AIG’s domestic insurance subsidiaries acquire liquidity through repo transactions, a securities borrowing facility (SBF) was instituted. Cumulatively, the SBF lent $\$ 802.316$ billion in direct credit in the form of repos against AIG collateral. As a further step in addressing AIG’s problems maintaining liquidity and staving off capital pressures, an SPV, Maiden Lane II, LLC (ML II), was created with a $\$ 19.5$ billion loan from the FRBNY to purchase residential MBS from AIG's securities lending portfolio. The proceeds received by AIG in the sale of its residential MBS portfolio were used to repay the SBF and terminate that program. To address the greatest threat to AIG's restructuring-losses associated with the sizeable book of collateralized debt obligations (CDOs) on which it had written credit default swaps (CDS) - another SPV, Maiden Lane III, LLC (ML III), was funded by a FRBNY loan to purchase AIG's CDO portfolio. The purchases by ML III totaled $\$ 24.3$ billion. 
As part of AIG's divestiture program, the Fed conducted transactions on December 1, 2009 in which the FRBNY received preferred interests in two SPVs created to hold the outstanding common stock of AIG's largest foreign insurance subsidiaries, American International Assurance Company (AIA) and American Life Insurance Company (ALICO). On September 30, 2010 an agreement was reached between the AIG, the Fed, the U.S. Treasury, and the SPV trustees regarding the AIA/ALICO transactions to facilitate the repayment of AIG's outstanding obligations to the United States government. AIG, the Treasury, and the FRBNY announced the closing of the recapitalization plan announced on September 30, 2010, and all monies owed to the RCF were repaid in full January 2011. Section 13(3) of the FRA was invoked to conduct each facility providing AIG direct assistance. Table 10 lists the specific total dollar amount for facilities providing AIG with assistance and the amount outstanding as of November 10, 2011.

Table 10 Facilities providing AIG with assistance, in billions

\begin{tabular}{lll} 
Facility & Total & $\begin{array}{l}\text { Amount outstanding as of } \\
\mathbf{1 1} / \mathbf{1 0} / \mathbf{2 0 1 1}\end{array}$ \\
\hline RCF & $\$ 140.316$ & $\$ 0$ \\
SBF & 802.316 & 0 \\
Maiden Lane II & 19.5 & 9.336 \\
Maiden Lane III & 24.3 & 18.049 \\
Preferred Interests in AIA/ ALICO & 25 & 0
\end{tabular}

Source: Federal Reserve

Stage Two: Restart the Flow of Credit by Direct Purchases of Assets

The second stage of actions taken by the Fed represent an even larger departure from conventional LOLR operations when the Fed, in an attempt to circumvent the inability (or unwillingness) of financial institutions to engage in the intermediation process, chose to extend loans directly to support what were viewed as critical credit markets. The goal of the Fed in this stage of the bailout was to restart the flow of credit to households and businesses by buying assets in exchange for the most risk-free and liquid of assets-reserves.

The Fed's first foray into supporting key credit markets occurred in the aftermath of Lehman Brothers’ bankruptcy. On September 1, 2008, the Reserve Primary Fund, the oldest money market mutual fund (MMMF) in the U.S., lowered its share price below $\$ 1$ and "broke the buck." As a response to the uncertainty regarding the value of positions in MMMFs, investors scrambled to withdraw funds. During the week of September 15, investors withdrew 
$\$ 349$ billion. The total withdrawn in the following three weeks amounted to an additional \$85 billion (Financial Crisis Inquiry Comission 2011, p. 357). To meet withdrawal requests, many mutual funds were forced to sell assets, triggering increased downward pressure on asset prices. The creation of the AMLF was an attempt to forestall the liquidation of assets by funds, and therefore prevent further deflation in asset prices. The Fed responded to this series of events with a facility targeting the MMMF market.

The Asset-Backed Commercial Paper Money Market Mutual Fund Liquidity Facility (AMLF) was designed to extend nonrecourse loans to intermediary borrowers at the primary credit rate. On the same day the AMLF loan was issued, intermediaries used these funds to purchase high quality asset-backed commercial paper (ABCP) issued by MMMFs. The indirect process adopted was necessitated by "statutory and fund-specific limitations," which prevented the MMMFs from borrowing directly from the Fed. The primary intention of the AMLF was to allow MMMFs to fund themselves by issuing ABCP to be purchased by intermediaries, with the larger goal of the program being to provide liquidity in the broader money markets (Federal Reserve 2009a, p. 53). The AMLF was announced on September 19, 2008 and executed by the Federal Reserve Bank of Boston (FRBB). All loans were fully collateralized and borrowers and intermediaries were subject to eligibility requirements. To ensure that the AMLF was being used in accordance with its stated purpose, the Fed would later require MMMFs to provide proof of material outflows prior to selling ABCP under the AMLF program (Federal Reserve 2009b). The authorization for the AMLF program would again come from Section 13(3) of the FRA.

Two institutions, J.P. Morgan Chase and State Street Bank and Trust Company, constituted 92 percent of AMLF intermediary borrowing; see Table 11. Over the course of the program, the Fed would lend a total of $\$ 217.435$ billion. As can be seen in Figure 12, peak weekly lending and amount outstanding reached their apex on the week of Sepember 25, 2008 at $\$ 88.6$ and $\$ 152.1$ billion on October 2, 2008 respectively. The nine largest sellers of ABCP are listed in Table 12. Funds 
Table 11 AMLF buyers of ABCP, in billions

\begin{tabular}{lll} 
Parent Company & $\begin{array}{l}\text { Total AMLF } \\
\text { borrowing }\end{array}$ & $\begin{array}{l}\text { Percent of } \\
\text { total }\end{array}$ \\
\hline J.P. Morgan Chase & $\$ 114.4$ & $51.3 \%$ \\
State Street Bank and Trust Company & 89.2 & 41.1 \\
Bank of New York Mellon & 12.9 & 5.9 \\
Bank of America & 1.6 & 0.7 \\
Citigroup & 1.4 & 0.7
\end{tabular}

Source: Federal Reserve

Figure 12 AMLF, weekly amounts lent and outstanding, in billions

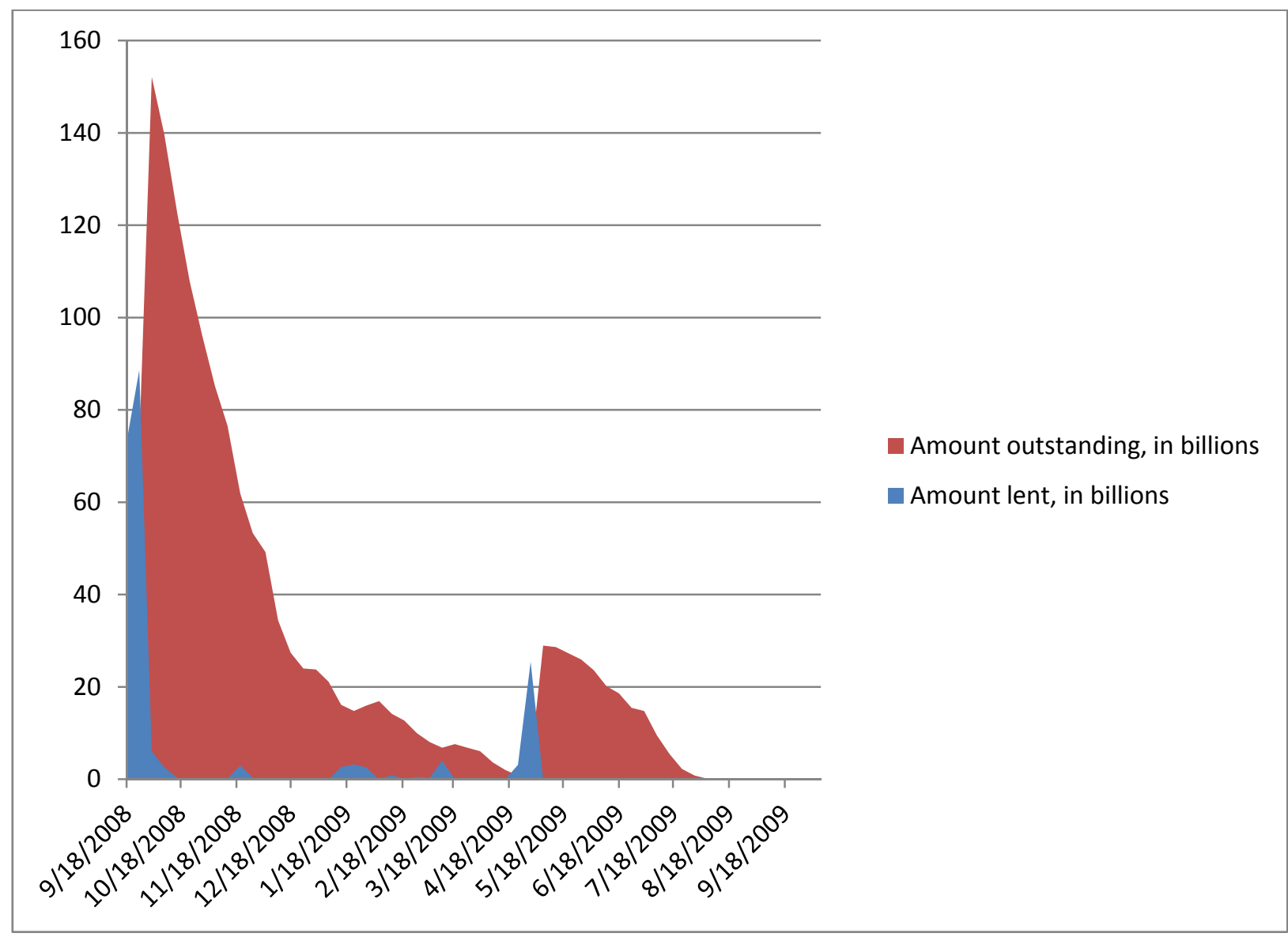

Source: Federal Reserve

selling in excess of $\$ 10$ billion comprised roughly 58 percent of overall ABCP sales. All loans are said to have been repaid in full, with interest, in agreement with the terms of the facility. The AMLF was closed on February 1, 2010. 
Table 12 Nine largest sellers of ABCP under AMLF program, in billions

\begin{tabular}{lll} 
Fund Family Seller & $\begin{array}{l}\text { Total AMLF } \\
\text { sales }\end{array}$ & $\begin{array}{l}\text { Percent of } \\
\text { Total }\end{array}$ \\
\hline Reserve Funds & $\$ 19$ & $8.9 \%$ \\
J.P. Morgan Chase & 18 & 8.1 \\
Dreyfus & 17 & 7.6 \\
Columbia Funds & 15 & 6.9 \\
Barclays & 13 & 5.9 \\
Wells Fargo & 12 & 5.6 \\
BlackRock & 12 & 5.5 \\
Federated & 10 & 4.7 \\
Morgan Stanley & 10 & 4.4 \\
All others & 92.01 & 42.4
\end{tabular}

Source: Federal Reserve

Despite providing support to the MMMFs through the AMLF so as to prevent redemption requests from having a disruptive effect on debt markets, MMMFs showed little inclination to resume their purchases of commercial paper (CP). Uncertain about counterparty credit risk and their own liquidity risk, MMMFs shifted their portfolios toward more secure assets, such as U.S. Treasuries (Anderson and Gascon 2009). As a consequence of the "flight to safety” by market participants, credit markets essentially "froze up," stalling the flow of credit to households and businesses. To address this disruption, the Fed announced the Commercial Paper Funding Facility (CPFF) on October 7, 2008. This facility was authorized under Section 13(3) of the FRA and was designed to improve liquidity in CP markets. The program was structured to operate through an SPV since the CPFF's logistics fell outside the Fed's traditional operating framework. The SPV provided assistance by purchasing highly rated ABCP and unsecured U.S. dollar-denominated CP of three month maturity from eligible issuers. To manage credit risk the Fed attached fees to program participation, collecting \$849 million from program participants, according to the Fed's website.

A total of 120 unique institutions took part in this facility. The top ten borrowers (each borrowing in excess of $\$ 20$ billion) account for 64.3 percent ( $\$ 473.9$ billion) of all borrowingsee Table 13 and Figure 13. The cumulative total lent under the CPFF was $\$ 737.07$ billion. Peak lending occurred during the first week of operations at $\$ 144.59$ billion, and the largest amount outstanding occurred on January 22, 2009 at \$348.176 billion; see Figure 14. The CPFF was suspended on February 1, 2010 and all loans are said be paid in full under the terms and conditions of the program. 
Table 13 Top ten CPFF borrowers, in billions

\begin{tabular}{lllll} 
Borrower & ABCP & Unsecured CP & Issuer total & $\begin{array}{l}\text { Percent of } \\
\text { CPFF total }\end{array}$ \\
\hline UBS (Switzerland) & & & $\$ 74.5$ & $10.1 \%$ \\
AIG & $\$ 0.0$ & $\$ 74.5$ & 60.2 & 8.2 \\
Dexia SA (Belgium) & 36.0 & 24.0 & 53.5 & 7.3 \\
Hudson Castle & 0.0 & 53.5 & 53.3 & 7.2 \\
BSN Holdings (United Kingdom) & 53.3 & 0 & 42.8 & 5.8 \\
The Liberty Hampshire Company & 41.8 & 0.0 & 41.4 & 5.6 \\
Barclays PLC (United Kingdom) & 0.0 & 0 & 38.8 & 5.3 \\
Royal Bank of Scotland Group & 24.8 & 38.8 & 38.5 & 5.2 \\
(United Kingdom) & & 13.7 & & 5.2 \\
Fortis Bank SA/NV & 26.9 & 11.6 & 38.5 & 4.3 \\
Citigroup & 12.8 & 19.9 & 32.7 &
\end{tabular}

Source: Federal Reserve

Figure 13 CPFF borrowing by institution

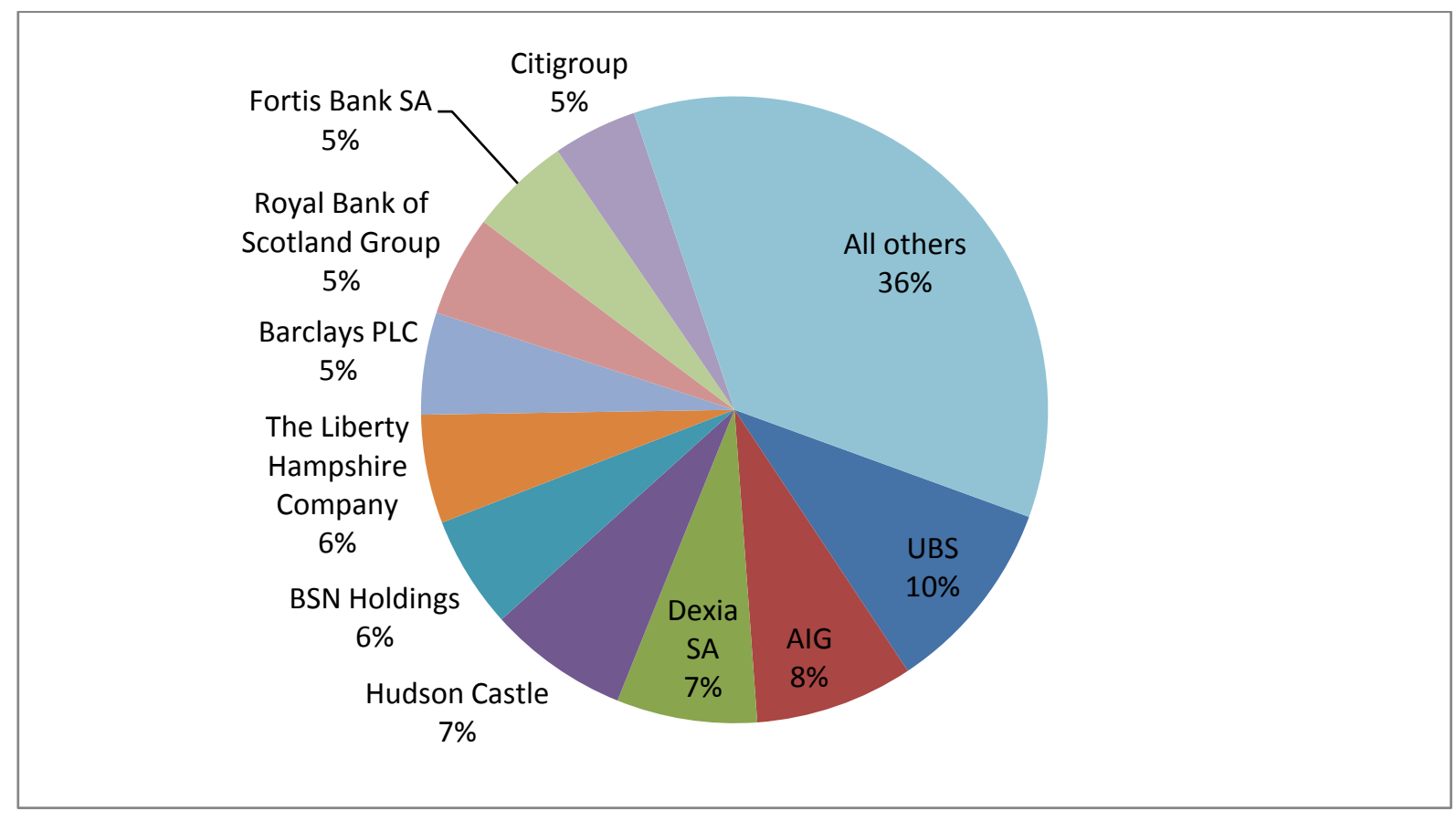

Source: GAO

Despite the CPFF and AMLF being implemented to improve conditions in credit markets, pervasive uncertainty resulted in rising credit standards. At the time, it was believed that upwards of 70 percent of banks tightened standards (Federal Reserve 2009c, p. 8). Financial innovation in the credit intermediation process over the 20 years preceding the crisis had resulted in the development of an "originate and distribute” model in which pools of loans were packaged by lenders and sold as fixed income products. The sale of securitized ABS products 
allowed lenders to move long-term (and illiquid) loans off their balance sheets and, in the process, collect immediate profits and funding with which to make new loans. To confront gridlock in ABS markets, and to increase the flow of credit throughout the U.S. economy, the Fed announced the creation of the Term Asset-Backed Securities Loan Facility (TALF) on November 25, 2008. Operating similarly to the AMLF, the Fed provided nonrecourse loans to eligible borrowers posting eligible collateral, but for terms of five years. Borrowers then would act as an intermediary, using the TALF loans to purchase ABS. These ABS were required to have received a credit rating in the highest investment-grade category by two approved ratings agencies and would serve as collateral for the TALF loan. The ABS categories eligible for issuance under the TALF included: auto loans, student loans, credit card loans, equipment loans, "floor-plan" loans, insurance premium finance loans, small business loans fully guaranteed by the U.S. Small Business Association, servicing advance receivables, and commercial mortgage loans. Authorization to conduct the TALF was provided under Section 13(3) of the FRA.

Figure 14 CPFF weekly amounts lent and outstanding, in billions

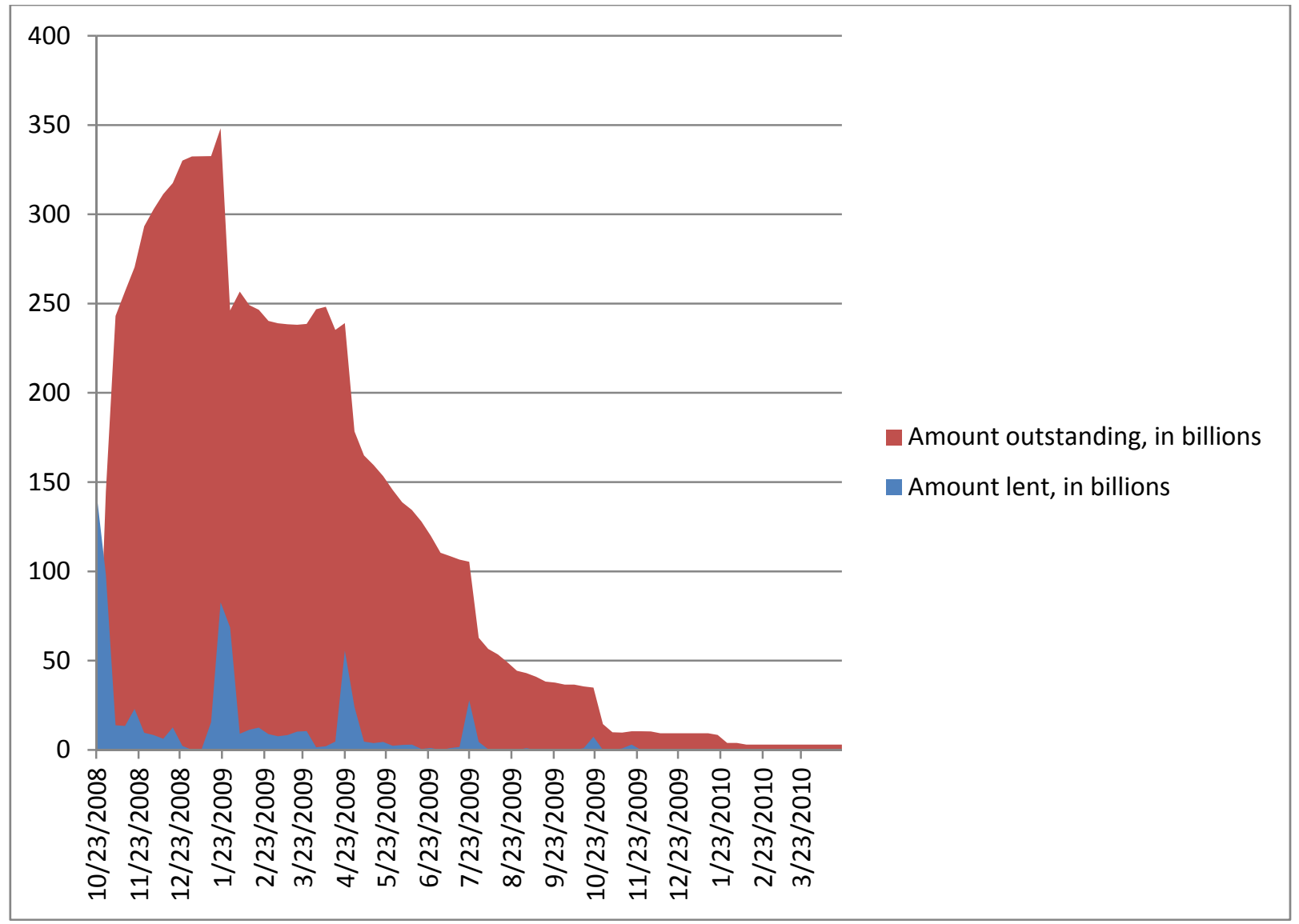

Source: Federal Reserve 
Although the Fed terminated lending under the TALF on June 30, 2010, loans remain outstanding under the program until March 30, 2015. The Fed loaned in total $\$ 71.09$ billion through this program. Significantly smaller in size than other emergency lending programs, the TALF's peak in terms of amount lent occurred the weeks beginning June 4, 2009 at \$10.72 billion, and after suspending operations, the amount outstanding peaked at $\$ 48.19$ billion on March 18, 2010; see Figure 15. Of the total 177 borrowers, those borrowing over $\$ 2$ billion constituted 58 percent (\$41.24 billion) of total borrowing; see Figure 16. The top five largest borrowers are depicted in Table 14, and comprise 41.7 (\$29.6) percent of total borrowing. Figure 17 presents the allocation of TALF loans by asset category. As of November 10, 2011, almost 15 percent of loans ( $\$ 10.571$ billion) remain outstanding. No collateral has yet to be surrendered due to default on payments.

Table 14 Top five TALF borrowers, in billions

\begin{tabular}{ll} 
Borrower & Tota \\
\hline Morgan Stanley & $\$ 9.3$ \\
PIMCO & 7.3 \\
CalPERS & 5.4 \\
Arrowpoint Capital & 4.0 \\
Angelo Gordon \& Co. & 3.7
\end{tabular}

Source: GAO

Figure 15 TALF weekly amounts lent and outstanding, in billions

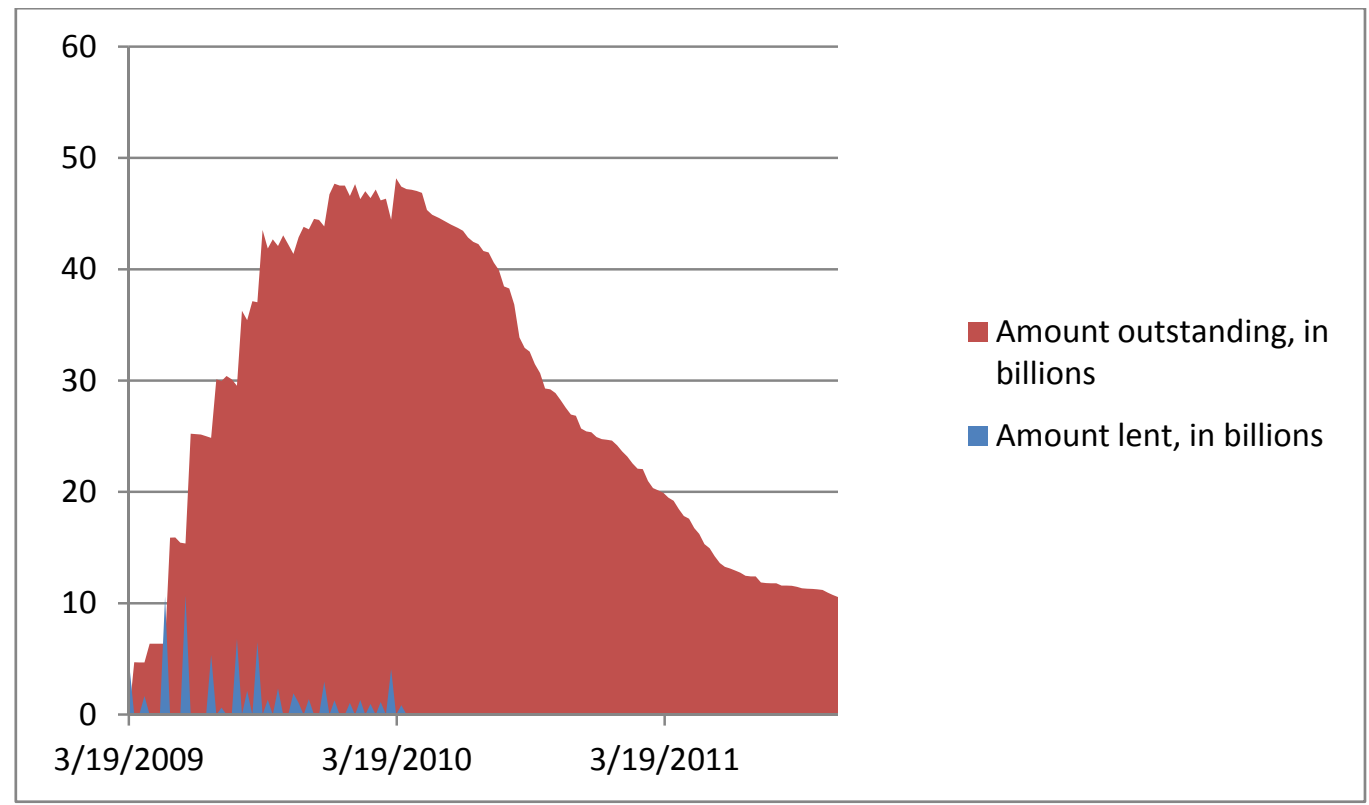

Source: Federal Reserve 
Figure 16 TALF borrowing by institution

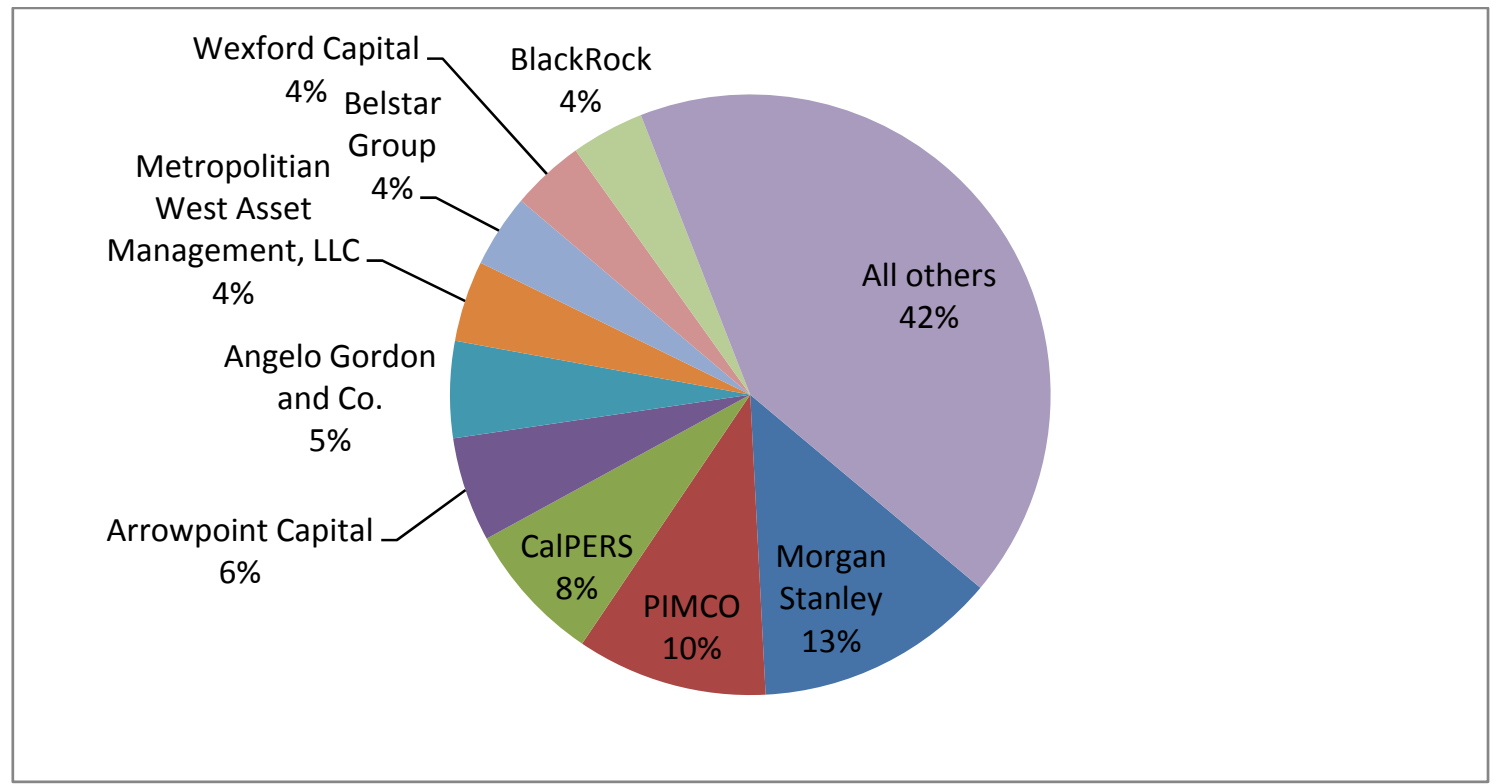

Source: GAO and Federal Reserve

\section{Stage Three: Purchases of Long-term Securities}

The final stage of the Fed's bailout is composed of the purchase of long-term securities in an attempt to support the functioning of credit markets (Bernanke 2009). Policy actions associated with this stage are the purchase of agency MBS and subsequent rounds of Quantitative Easing; the latter of which, while unconventional, is well-known to monetary policy theory and in practice, most noticeably by the example afforded by the Bank of Japan's monetary policy

Figure 17 TALF lending by asset category, percentage and total, in billions

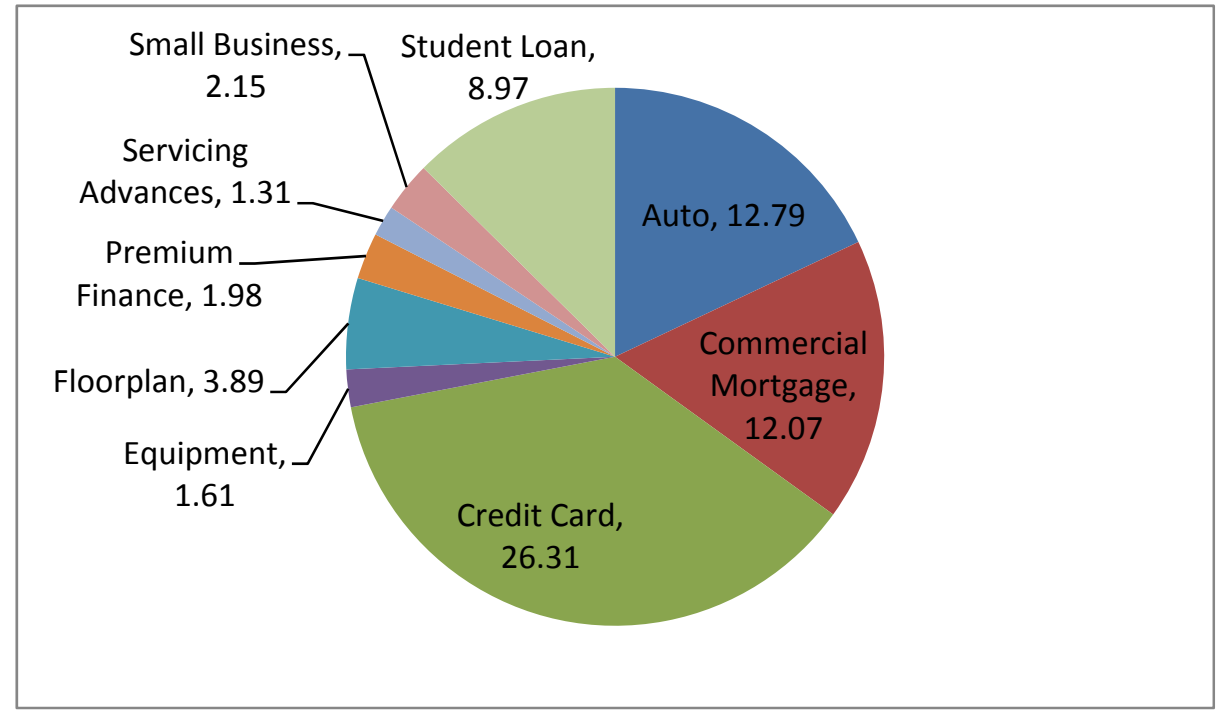

Source: Federal Reserve 
from the 1990s onward. Stage Three programs involve the "expansion of traditional open market operations support to the functioning of credit markets through the purchase of longterm securities for the Fed's portfolio" (Federal Reserve 2011b). Operations falling under this stage consist of the purchase of two types of medium- and-long-term securities: agency MBS and U.S. Treasury securities. As the purchase of Treasuries represents a weapon from the monetary policy arsenal, and therefore is not associated with LOLR operations, we will consider only the Fed's purchase of MBS in this section.

The Agency Mortgage-Backed Securities (MBS) facility was authorized by Section 14 of the FRA. It was created to stabilize the price of MBS, as well as to "increase the availability for credit for the purchase of houses, which in turn should support housing markets and foster improved conditions in financial markets more generally” (Federal Reserve 2008b). As of July 2010 , the Fed purchased some $\$ 1,850.14$ billion in MBS via open market operations conducted by the FRBNY. However, as the Fed was making purchases, it was simultaneously conducting sales - with net MBS purchases by the Fed at $\$ 1,250$ billion. Figure 18 indicates that the Fed's MBS holdings peaked at $\$ 1,128.67$ billion on June 23, 2010. The highest weekly purchases occurred for the week beginning April 12, 2009, when the Fed made gross purchases of $\$ 80.5$ billion. All transactions were conducted with primary dealers for MBS of three maturities: 15, 20, and 30 years - with the purchase of 30-year MBS comprising 95 percent of total purchases. Table 15 presents the top five sellers of MBS to the Fed. Figure 19 shows that the top 5 sellers accounted for 61.0 percent (\$1.145) of total MBS purchases. Of the 16 program participants, the 9 foreign primary dealers constituted over half (52 percent) or \$964.53 trillion of MBS sellers. This relationship is expressed in Figure 20.

Table 15 Top five sellers to MBS program, in billions

\begin{tabular}{ll} 
Seller & Total \\
\hline Deutsche Bank Securities & $\$ 293.325$ \\
Credit Suisse & 287.26 \\
Morgan Stanley & 205.71 \\
Citigroup & 184.95 \\
Merrill Lynch & 173.57
\end{tabular}

Source: Federal Reserve 
Figure 18 Weekly MBS purchases and amounts outstanding, in billions

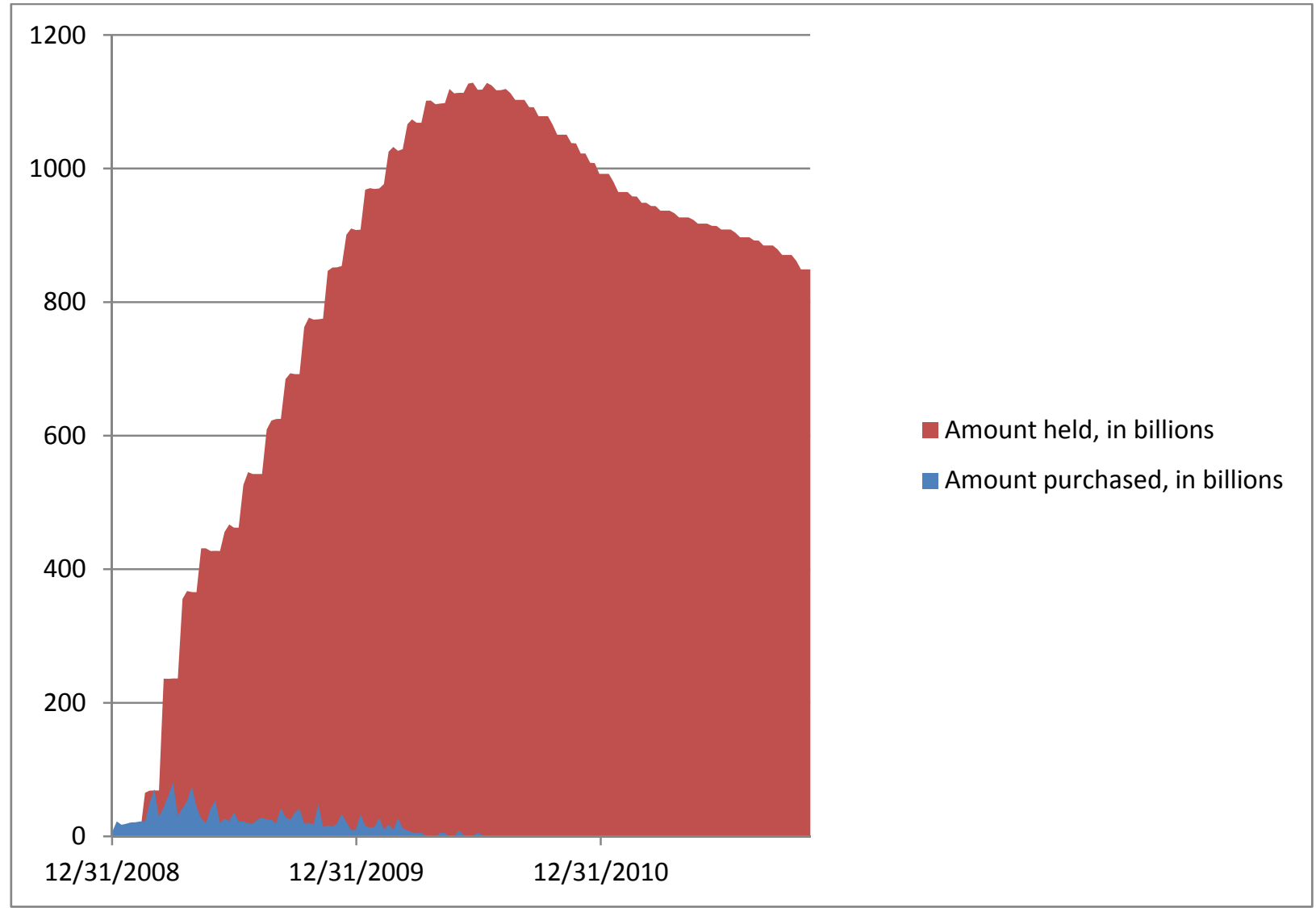

Source: Federal Reserve

Figure 19 Sales to MBS program by institution, in billions

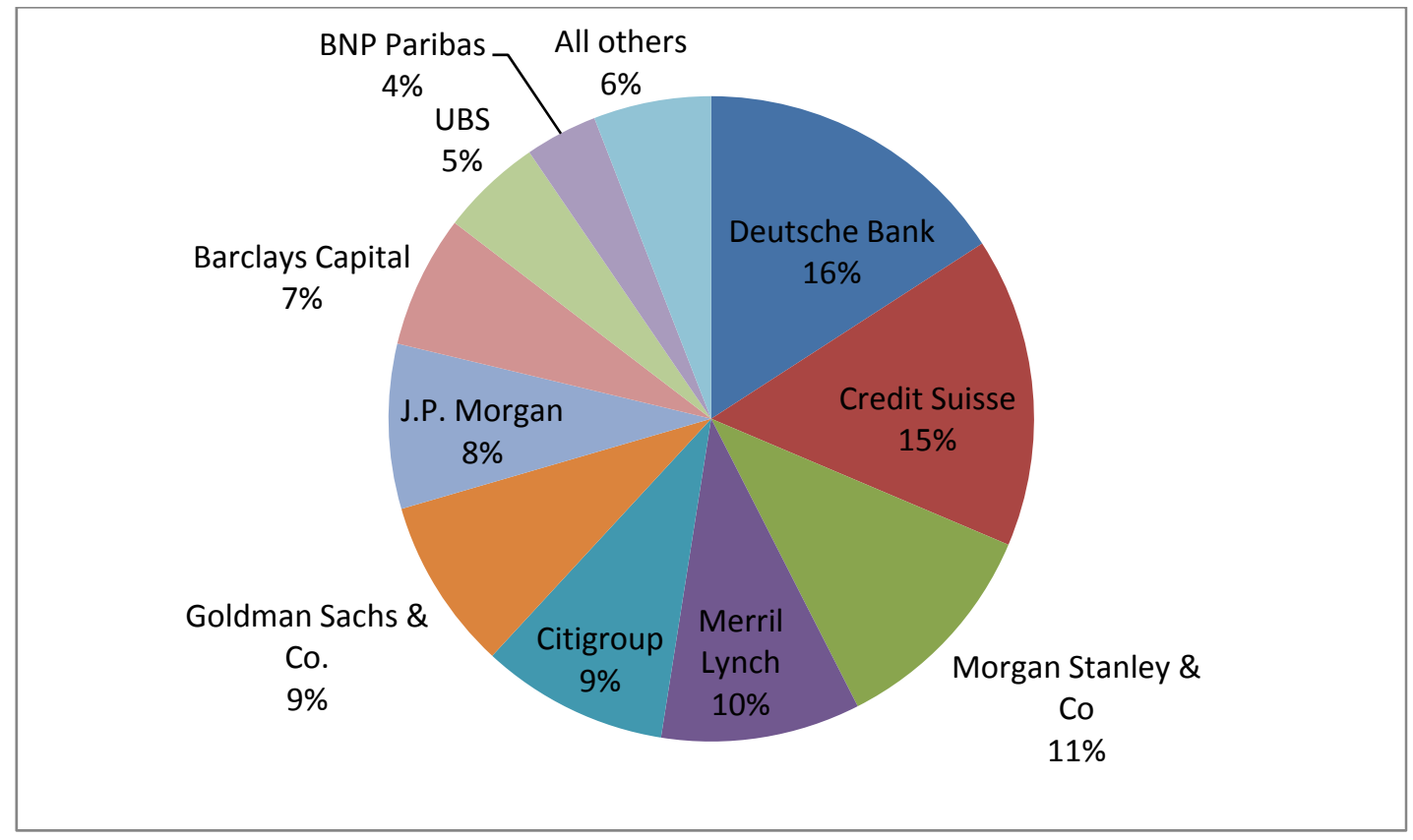


Source: Federal Reserve

Figure 20 MBS percentages purchases by country

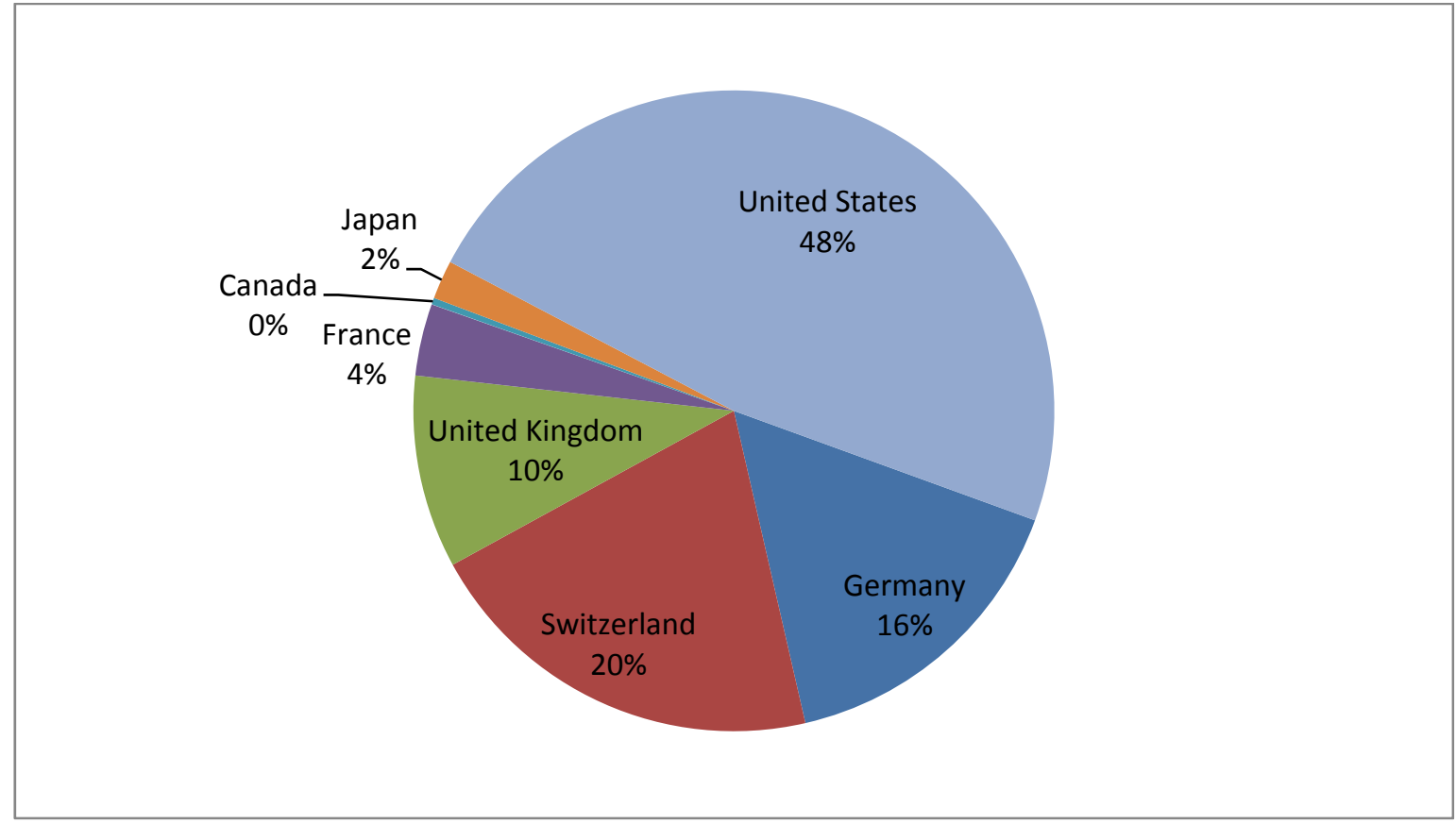

Source: Federal Reserve

\section{SUMMARY}

When all individual transactions are summed across all unconventional LOLR facilities, the Fed spent a total of $\$ 29,616.4$ billion dollars! Note this includes direct lending plus asset purchases. Table 16 and Figure 21 depict the cumulative amounts for all facilities; any amount outstanding as of November 10, 2011 is in parentheses below the total in Table 16. Three facilities-CBLS, PDCF, and TAF - would overshadow all other unconventional LOLR programs, and make up 71.1 percent ( $\$ 22,826.8$ billion) of all assistance. 
Table 16 Cumulative facility totals, in billions

\begin{tabular}{lll} 
Facility & Total & $\begin{array}{l}\text { Percent of } \\
\text { total }\end{array}$ \\
\hline Term Auction Facility & $\begin{array}{l}\$ 3,818.41 \\
10,057.4\end{array}$ & $\begin{array}{l}12.89 \% \\
(1.96)\end{array}$ \\
Central Bank Liquidity Swaps & 855 & 2.89 \\
Single Tranche Open Market Operation & $2,005.7$ & 6.77 \\
Terms Securities Lending Facility and Term Options & 12.9 & 0.04 \\
Program & 28.82 & 0.10 \\
Bear Stearns Bridge Loan & $(12.98)$ & \\
Maiden Lane I & $8,950.99$ & 30.22 \\
Primary Dealer Credit Facility & 217.45 & 0.73 \\
Asset-Backed Commercial Paper Money Market Mutual & & \\
Fund Liquidity Facility & 737.07 & 2.49 \\
Commercial Paper Funding Facility & 71.09 & 0.24 \\
Term Asset-Backed Securities Loan Facility & $(10.57)$ & \\
Agency Mortgage-Backed Security Purchase Program & $1,850.14$ & 6.25 \\
AIG Revolving Credit Facility & $(849.26)$ & \\
AIG Securities Borrowing Facility & 140.316 & 0.47 \\
Maiden Lane II & 802.316 & 2.71 \\
Maiden Lane III & 19.5 & 0.07 \\
AIA/ ALICO & $\mathbf{( 9 . 3 3 )}$ & \\
\hline Totals & 24.3 & 0.08 \\
\hline
\end{tabular}

Source: Federal Reserve

Figure 21 Facility percentage of bailout total

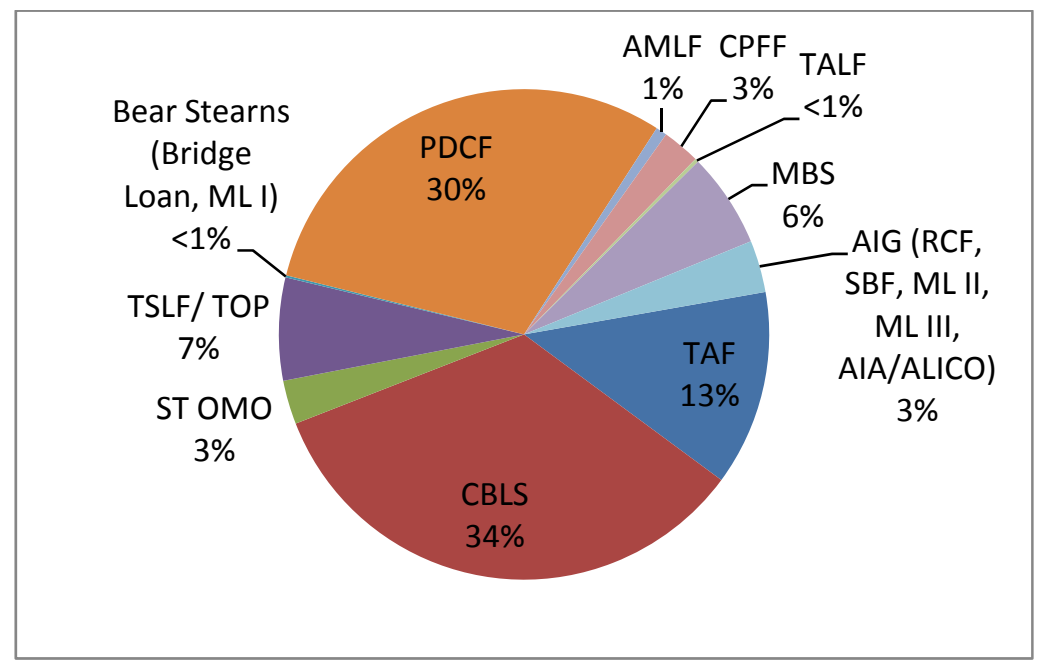

Source: Federal Reserve

The cumulative total for individual institutions provides even more support for the claim that the Fed's response to the crisis was truly a bailout (of unprecedented proportions) and was 
targeted at the largest financial institutions in the world. If the CBLS are excluded, 83.9 percent (\$16.41 trillion) of all assistance would be provided to only 14 institutions. Table 17 and Figure 22 display the degree to which a few Too Big To Fail institutions received the preponderance of support from the Fed. We note in passing that the six largest foreign-based institutions would receive 36 percent (\$10.66 trillion) of the total bailout.

Table 1714 largest participants (excluding CBLS), in billions

\begin{tabular}{lll} 
Participant & Total & $\begin{array}{l}\text { Percentage of } \\
\text { total }\end{array}$ \\
\hline Citigroup & $\$ 2,654.0$ & $13.6 \%$ \\
Merrill Lynch & $2,429.4$ & 12.4 \\
Morgan Stanley & $2,274.3$ & 11.6 \\
AIG & $1,046.7$ & 5.4 \\
Barclays (UK) & $1,030.1$ & 5.3 \\
Bank of America & $1,017.7$ & 5.2 \\
BNP Paribas (France) & $1,002.2$ & 5.1 \\
Goldman Sachs & 995.2 & 5.1 \\
Bear Stearns & 975.5 & 5.0 \\
Credit Suisse (Switzerland) & 772.8 & 4.0 \\
Deutsche Bank (Germany) & 711.0 & 3.6 \\
RBS (UK) & 628.4 & 3.2 \\
JP Morgan Chase & 456.9 & 2.3 \\
UBS (Switzerland) & 425.5 & 2.2 \\
All others & $3,139.3$ & 16.1 \\
\hline Totals & $\mathbf{\$ 1 9 , 5 5 9 . 0 0}$ & $\mathbf{1 0 0} \%$ \\
\hline
\end{tabular}

Source: Federal Reserve

Figure 23 Total participation by institution, excluding CBLS, in billons

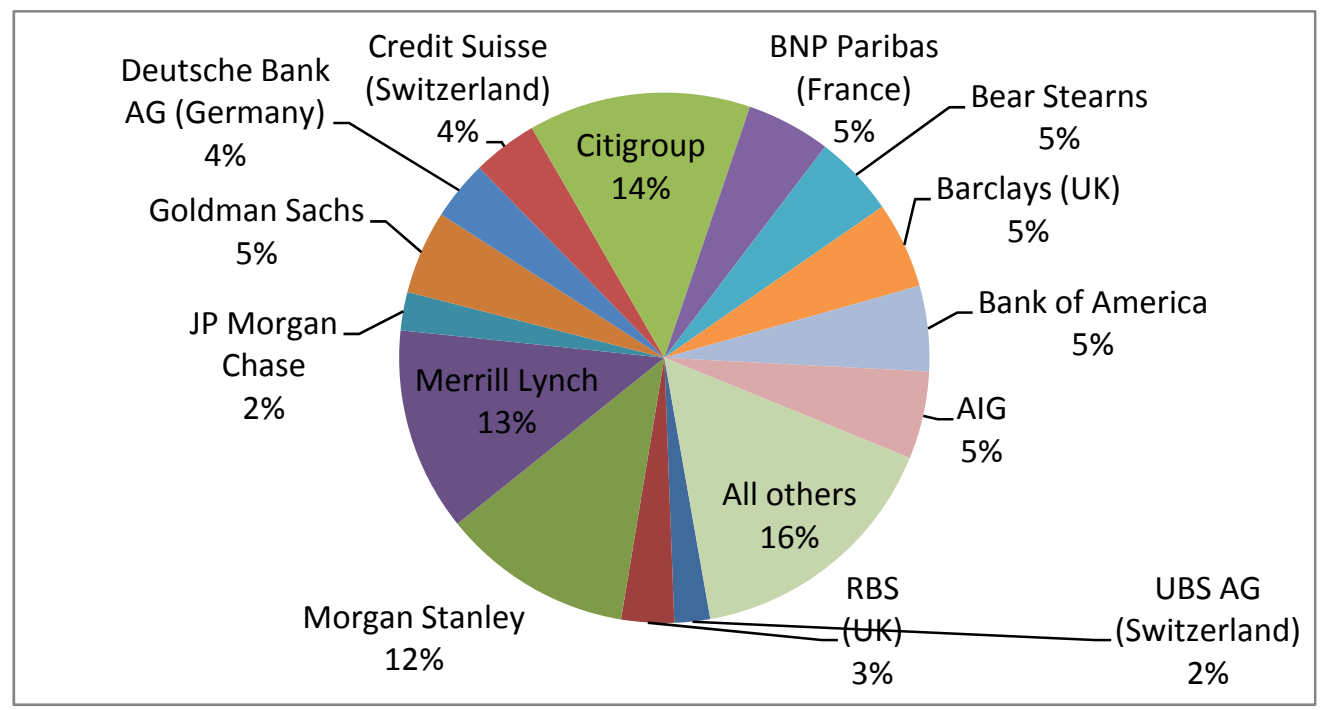

Source: Federal Reserve 


\section{CONCLUSION}

The Global Financial Crisis of 2007-2009 is remarkable for a number of reasons. On one hand, it represents the explosion of the idealistic vision of efficient financial markets in which financial innovation and deregulation had conquered the eternal bugbear of financial instability, and resulted in a golden age called the "Great Moderation.” On the other hand, it exposed the lengths to which central banks worldwide — the Fed being perhaps the best example-would act to save the existing financial order, helping to preserve especially the largest and most powerful institutions. We will never know what might have happened had there not been such a strong intervention. The best we can do is study the methods through which central banks prevented what surely would have been financial Armageddon. This short paper makes a first attempt at doing just that.

This is the first of what we intend to be a series of working papers on the Fed's bailout. In this one, we have focused on an accounting of the funds spent, by facility. We have also tallied how much the largest institutions received. Finally, we have indicated where foreign institutions have received substantial help, including both foreign central banks as well as private banks. In subsequent papers we will provide more detail on some of the Fed's actions, and will also discuss implications concerning such matters as risks to the Fed and Treasury of losses due to the Fed's expenditures, as well as matters related to Congressional oversight and accountability of the Fed. 


\section{REFERENCES}

Adrian, T., Christopher R. Burke, and James J. McAndrews. 2009. “The Federal Reserve’s Primary Dealer Credit Facility.” Federal Reserve Bank of New York Current Issues 15(4):1-10.

Anderson, R.G. and Charles S. Gascon. 2009. "The Commercial Paper Market, the Fed, and the 2007-2009 Financial Crisis.” The Federal Reserve Bank of St. Louis Review 91(6):589612.

Bernanke, B.S. 2009. "The Crisis and the Policy Response.” Speech at the Stamp Lecture, London School of Economics, London, England, January 13, 2009.

Board of Governors of the Federal Reserve System. 2009. 95 ${ }^{\text {th }}$ Annual Report.

Federal Reserve. 2007. "Federal Reserve Actions.” Federal Reserve press release, December 12, 2007.

. 2008a. "Federal Reserve Actions." Federal Reserve monetary policy release, March 11, 2008.

. 2008b. Federal Reserve monetary policy release, November 25, 2011. . 2009a. 95 ${ }^{\text {th }}$ Annual Report. June 2009.

. 2009b. Federal Reserve monetary policy release, January 30, 2009.

. 2009c. The January 2009 Senior Loan Officer Opinion Survey on Bank Lending Practices. Board of Governors of the Federal Reserve System.

. 2011a. Federal Reserve monetary policy release, June 29, 2011.

. 2011b. "Credit and Liquidity Papers and the Balance Sheet.” Federal Reserve Monetary Palicy, November 4, 2011.

Financial Crisis Inquiry Commission. 2011. The Financial Crisis Inquiry Report. Superintendent of Documents, U.S. Government Printing Office.

Minsky, H.P. 2008. Stabilizing An Unstable Economy. McGraw-Hill Inc. Originally published 1986.

Sarkar, Asani. 2009. Liquidity Risk, Credit Risk, and the Federal Reserve's Response to the Crisis. Staff Report 389, Federal Reserve Bank of New York. 